\section{AÑOS DE LA LEY DE REFORMA URBANA EN CUBA. EN EL ANIVERSARIO DEL CAMBIO DE PARADIGMA ${ }^{1}$}

Erich Trefftz $z^{2}$

\section{Resumen}

La contribución brinda una visión general de las condiciones del hábitat pre revolucionario en Cuba, específicamente en La Habana. Explica las primeras medidas revolucionarias en la política de la vivienda y la Ley de Reforma Urbana, que transformó con sus decisiones de principios el sistema de la vivienda en Cuba. Analiza los resultados y contradicciones que prevalecen hasta hoy. Se presentan y discuten los resultados de una encuesta conducida entre marzo y junio de 2010 con casi cien expertos en el tema de la vivienda, que finalmente se contraponen con los cambios por venir, introducidos por los nuevos lineamientos para la política económica y social aprobada en el reciente congreso del partido.

\section{YEARS OF THE URBAN REFORM LAW IN CUBA. THE ANNIVERSARY OF THE PARADIGM SHIFT ${ }^{1}$}

\author{
Erich Trefftz $z^{2}$
}

\begin{abstract}
This paper provides an overview of the prerevolutionary housing conditions in Cuba and especially in Havana. It explains the first revolutionary measures regarding housing and the Urban Reform Law, the latter transforming the Cuban housing system. This paper also analyzes today's results and contradictions. Additionally, the outcomes of a survey conducted between March and June, 2010 to almost a hundred experts are presented and discussed. Finally, the survey findings are contrasted with the changes introduced by the new guidelines for economic and social policies passed in the last party congress.
\end{abstract}

revista invi № 72 / August 2011 / Volume № 26: 19-62 
PALABRAS CLAVE: CUBA, REFORMA URBANA, POLÍTICA DE VIVIENDA, MERCADOS DE VIVIENDA.

Fecha de recepción: 07.03.11

Fecha de aceptación: 10.06.11

1 Tesis doctoral titulada "Estrategias para el manejo de la vivienda en la rehabilitación urbana de los barrios céntricos de La Habana", tutelada por el urbanista Dr. Mario Coyula para postular al grado de Doctor en Ciencias Técnicas de la Facultad de Arquitectura en el Instituto Superior Politécnico José Antonio Echeverría.

2 Cuba. Licenciado en Economía de la Universidad Otto-Friedrich de Bamberg, Máster en Arquitectura, opción Vivienda Social, en el Instituto Superior Politécnico José Antonio Echeverría, con una tesis sobre "Política y propiedad de la vivienda en Cuba, un análisis histórico y comparativo". Estudiante de doctorado en la Facultad de Arquitectura del Instituto Superior Politécnico José Antonio Echeverría.Email: erich@trefftz.de

20 revista invi № 72 / Agosto 2011 / Volumen N ${ }^{0}$ 26: 19-62
KEY WORDS: CUBA, URBAN REFORM, HOUSING POLITICS, HOUSING MARKETS,

Received: 07.03.11

Accepted: 10.06.11

1 Doctoral thesis "Strategies for Housing Management in the Urban Rehabilitation of Havana's Downtown Districts", supervised by Mario Coyula, Ph.D., to apply for the Ph.D in Technical Sciences, Faculty of Architecture, Polytechnic José Antonio Echeverría.

2 Cuba. BA in Economics, Otto-Friedrich University of Bamberg. MA in Architecture, option in Social Housing, Polytechnic José Antonio Echeverría, with a thesis on "Politics and Home Ownership in Cuba, a Historical and Comparative Analysis". Doctorate student, Faculty of Architecture, Polytechnic José Antonio Echeverría. email: erich@trefftz.de

ARTICLE: 50 years of the urban reform law in Cuba. The anniversary of the paradigm shift

/ Erich Trefftz 
El presente artículo brinda en su primer apartado una breve descripción de la situación de partida en el período pre revolucionario del hábitat, su segundo apartado explica las primeras medidas en la política de la vivienda y la gran obra revolucionaria; en la materia, la Ley de Reforma Urbana (LRU) de octubre 1960. Sus decisiones de principio influyeron hasta la mitad de 2010 de manera decisiva en la política de vivienda en Cuba. El siguiente apartado analiza resultados de una encuesta conducida entre marzo y junio de 2010 con casi cien expertos en el tema de la vivienda sobre medidas socioeconómicas para el mejoramiento de la vivienda en La Habana.

En el mes del aniversario 50 de la LRU empezó el cambio oficial de paradigma, tarea nada fácil después de 50 años de primacía de lo político sobre lo económico. En el $6^{\text {to }}$ Congreso del partido, celebrado en Abril de 2011, fueron aprobados los nuevos lineamientos para la política económica y social de Cuba. En el apartado final estos cambios por venir son contrapuestos con los resultados de la encuesta y discutidos.

\section{El hábitat pre revolucionario en Cuba}

Para comprender mejor la situación pre revolucionaria de la vivienda resulta muy útil dividir las observaciones en dos partes: por una, la deman-
In its first part, this paper offers a brief description of the prerevolutionary situation of habitat. The second section of this article explains the first measures of the housing policy, as well as the Urban Reform Law (URL), enacted on October, 1960, which is regarded as the major revolutionary achievement. The decisions of principle of the URL greatly influenced Cuba's housing policy until 2010. The following part of this paper analyses the results of a survey conducted between March and June, 2010, which included about 100 housing experts addressing socio economic measures to improve housing in Havana.

The official paradigm shift started during the 50th anniversary of the URL; after 50 years of political prevalence over economic affairs, such a change does not seem easy. During the Sixth Congress of the Communist Party, which was held in 2011, new guidelines were approved for the economic and social policies of Cuba. The final part of this paper analyzes these changes and contrasts them with the results of the survey.

\section{The Prerevolutionary Habitat in Cuba}

In order to ensure a better understanding of the prerevolutionary housing situation, it is 
da habitacional concentrada en las pocas ciudades grandes, encabezadas por La Habana con aproximadamente un quinto de toda la población del país, y por otra, la situación de la vivienda de la población rural.

Observando la situación de la vivienda en La Habana, es posible constatar que hasta la primera mitad del siglo esta estaba determinada por un crecimiento extremadamente rápido de su población urbana $^{3}$, por una parte (demanda), y por la otra (oferta) por el carácter capitalista puramente privado de la oferta de viviendas. "La política habitacional en Cuba, hasta el triunfo de la revolución estaba fundada en dos principios, que corresponden a la ideología de la sociedad pre revolucionaria: la casi absoluta hegemonía de la actividad privada en la construcción de viviendas y la libre contratación en los arrendamientos, libertad esta que fue ligeramente moderada en los últimos años del periodo."

Si se revisan con detenimiento los resultados del censo de vivienda realizado en $1953^{5}$, se pone de manifiesto no solo la enorme segregación social de la población urbana, sino el inmenso abismo entre la ciudad y el campo. Según esa fuente, 75,8\%

3 Si en 1919 La Habana contaba con 432.721 habitantes, hasta 1953 esta cifra aumentó a 1.210.920, con 653.823 habitantes en el año 1931 y 935.670 habitantes en 1943. Cf. Acosta, Hardoy (1973), p. 78.

$4 \quad$ Vega Vega (1986), p.38.

5 Los Datos del Censo de 1953 fueron tomados de las obras de Fernández Núñez (1976) p. 40 y Acosta Hardoy (1973) p. 86. important to divide the observations into two parts: on the one hand, the housing demand taking place mostly on the few major cities lead by Havana, which concentrates a fifth of the country's population and, on the other hand, the housing situation of the rural population.

Until the first half of the XXth century, the housing situation in Havana was determined by the explosive growth of its urban population ${ }^{3}$ (demand) and the private capitalist nature of the housing supply. "The housing policy in Cuba, until the triumph of the revolution, was based on two principles related to the ideology of the prerevolutionary society: the almost complete control of the private sector over the construction of housing and freedom to rent; this latter activity was slightly regulated in the last years of this period 4 ."

When analyzing the results of the 1953 housing census ${ }^{5}$, apart from the high levels of segregation within the urban population, it also becomes clear the large gap between the

3 In 1919, Havana had a population of 432,721 ; in 1953, this figure grew to $1,210,929$, the city had 653,823 inhabitants in 1931 and 935,670 inhabitants in 1943. Acosta, Hardoy (1973), p. 78.

$4 \quad$ Vega Vega (1986), p. 38.

5 Information regarding the 1953 census was retrieved from Fernández Núñez (1976) p. 40 and Acosta Hardoy (1973) p. 86. 
de todas las viviendas rurales fueron clasificadas como malas o en ruinas, frente a un $30 \%$ de las viviendas en las ciudades; solo un 9,1\% frente a un 87\% en las ciudades disponían de electricidad... esta lista podría ser ampliada a voluntad.

Como los inversionistas y empresas de construcción de viviendas trabajan según el principio de maximización de los beneficios, la actividad de construcción de nuevas viviendas se limitó en gran medida a la edificación de casas y lujosos apartamentos ${ }^{6}$ para las clases adineradas, la construcción de pequeñas casas en nuevas zonas residenciales apartadas y la construcción de pequeñas viviendas situadas en zonas céntricas para ser alquiladas a la clase media. En correspondencia con la teoría neoliberal de Filtrado ${ }^{7}$, para la clase media baja y baja solo quedaba la posibilidad de mudarse a las antiguas grandes casas coloniales, entonces vacías y divididas en pequeñas unidades habitacionales, convertidas en lo que se conoce ahora como casas de vecindad. La clase baja (que no contaba con ingresos regulares) quedaba abandonada a su libre albedrío; para ellos la única solución era cons-

6 Para crear condiciones claras de propiedad se proclamó una ley sobre la propiedad horizontal (Ley Decreto del 16 de septiembre de 1952), que por el alcance de sus regulaciones se corresponde aproximadamente con la ley alemana de la propiedad de la vivienda. Sobre la historia de su surgimiento, de su carácter jurídico, la muy minuciosa obra de Gómez Gil (1954).

7 Según la Teoría de Filtrado la construcción de viviendas nuevas para la clase adinerada provoca cadenas de mudanzas, y al final de estas también las clases pobres mejoran su hábitat. city and the countryside. According to this source of information, $75.8 \%$ of rural dwellings were classified as of bad quality or in ruins; in contrast, only $30 \%$ of urban dwellings received this qualification. Likewise, while only $9.1 \%$ of rural homes had access to electricity, 87\% of urban homes enjoyed this service.

Since investors and building contractors work according to the profit maximization principle, new construction of housing was mostly delimited to houses and luxurious apartments ${ }^{6}$ aimed at well-off groups and small houses located on distant or central areas that were expected to be rented by the middle-class. By following the neoliberal Filtrado theory ${ }^{7}$, for low and middle income classes the only option was to move to large and old uninhabited colonial houses that were divided into small housing units. Today, such houses are known as tenement houses. The lower-class (which did not receive regular income) was left to its own

6 The horizontal property law (Decree Law 09.16.52) was enacted to create clear ownership conditions. This law bears a resemblance with the German home ownership law. For information about the history and legal nature of this act, see Gómez Gil (1954.)

7 According to the Filtering Theory, the construction of dwellings for well-off groups involves a string of removals. Poor classes are at the end of this chain, they also improve their habitat. 
truirse una choza improvisada con materiales de desperdicio en uno de los barrios marginales que proliferaban en La Habana.

Los arrendatarios representaban $3 / 5$ de los hogares urbanos e incluso 3/4 de los núcleos familiares de La Habana; constituían, por tanto una capa de la población a tener en cuenta desde el punto de vista político y de la táctica electoral. A causa de su elevado grado de organización, ellos habían logrado en las décadas que precedieron al triunfo de la Revolución derechos y protección que no quedaban a la zaga de la situación jurídica de la mayoría de los Estados federales de los EE.UU., al menos desde el punto de vista teórico ${ }^{8}$. De este modo, ante el trasfondo de la gran crisis económica de la década de los treinta y de la insolvencia e incapacidad de pago (del alquiler) por parte de amplios círculos de la población, a solicitud del llamado Comité Central de la Unión General de Arrendatarios, se promulgó el Decreto No 2005 del 30 de septiembre de 1933, el cual consiguió una prórroga para los procesos de desahucio y las demandas de desalojo.

En diciembre de ese mismo año se fijó la cantidad máxima permisible de procesos de desahucio y demandas de desalojo a 10 por juez y por día. En el año 1939 se congelaron los alquileres y se estableció legalmente un derecho a la vivienda y a

8 Hamberg (1994), p.19, para la siguiente exposición detallada en particular Vega Vega (1976), p.38. devices. The only solution for this group was the construction of makeshift huts made out of waste materials; these houses were located on the slums that proliferated in Havana.

Tenants represented three-fifths of urban houses and three-fourths of families lived on rented houses in Havana. Moreover, this section of the population was important for political and electoral purposes. Because of its high organizational level, prior to the Revolution, this group achieved rights and protection theoretically equal to those enjoyed by most of the States within the United States ${ }^{8}$. Therefore, in the light of the Great Depression and insolvency and default of payment (rents), the Decree 2005/10.30.33 was enacted at the request of the "General Committee of Tenants". Such decree involved an extension for eviction processes.

In December the same year, the maximum amount of evictions and eviction orders was set at 10 per day. In 1939, all rents were frozen and the right to housing and the right to remain were legally established ${ }^{9}$. However, ingenuity of tenants and the possibilities to evade these

Hamberg (1994), p.19; Vega Vega (1976), p.38.

Vega Vega (1984), p.39. 
la permanencia. ${ }^{9}$ Pero la ingeniosidad de los arrendatarios y las posibilidades de evadir esas disposiciones legales eran ilimitadas: Se alquilaban solo viviendas amuebladas, pidiéndose por los muebles alquileres exorbitantes; se exigía pago anticipado o pagos de indemnización, o sencillamente solo se extendían contratos de subarrendamiento, para los cuales no eran aplicables las legislaciones sobre monto máximo de los alquileres.

Es lógico que en el marco del sistema neoliberal de la vivienda, en que no se toman en consideración los intereses sociales y en donde el único objetivo es un rédito de capital lo más alto posible, la cuestión de la vivienda ocupara un lugar destacado en el programa político ${ }^{10}$ de los revolucionarios que se agruparon en torno a Fidel Castro.

En su célebre alegato de defensa en el juicio a los asaltantes del Cuartel Moncada el 26 de julio de 1953, Fidel Castro señaló lo siguiente acerca de la situación de la vivienda:

"Tan grave o peor es la tragedia de la vivienda. Hay en Cuba doscientos mil bohíos y chozas; cuatrocientas mil familias del campo y de la ciudad viven hacinadas en barracones, cuarterías y solares sin las más elementales condiciones de higie-

9 También Vega Vega (1984), p. 39.

10 De este modo, el problema de la vivienda era uno de los 6 puntos que se debían acometer tan pronto triunfara la Revolución y se tomara el poder. Los otros 5 puntos eran: educación, salud, empleo, industrialización y reforma agraria. Castro (1953), p. 36 legal provisions were unlimited. Only furnished dwellings were rented so that people had to pay excessive rents for the furniture; prepayment or compensation payment was required; in some cases only a sub-leased contract was signed, in which regulations for maximum payment of rent were not applicable.

It is logical that within the framework of the housing's neoliberal system, where social interests were not taken into consideration, and where the only objective was to obtain the highest possible profit, the housing issue had an important role in the political program ${ }^{10}$ of the revolutionary movement led by Fidel Castro.

In his famous defense statement during the trial against the people who stormed the Moncada Barracks on July 26, 1953, Fidel Castro said:

"The tragedy of housing is serious, or even worse. There are two hundred thousand huts and shacks; there are four hundred thousand families from the countryside living crowded together in cabins, tenements and estates without basic hygiene and health conditions;

10 In this way, housing was one of the six issues that had to be addressed after the triumph of the Revolution. The six remaining points were education, health, employment, industrialization and land reform. Castro (1953), p. 36. 
ne y salud, dos millones doscientas mil personas de nuestra población urbana pagan alquileres que absorben entre un quinto y un tercio de sus ingresos, y dos millones de nuestra población rural y suburbana carecen de luz eléctrica. Aquí ocurre lo mismo si el Estado se propone rebajar los alquileres: los propietarios amenazan con paralizar todas las construcciones; si el Estado se abstiene, construyen mientras pueden percibir un tipo elevado de renta, después no colocan una piedra más aunque el resto de la población viva a la intemperie. Otro tanto hace el monopolio eléctrico: extiende las líneas hasta el punto donde pueda percibir una utilidad satisfactoria; a partir de allí no le importa que las personas vivan en las tinieblas por el resto de sus días. El Estado cruza sus brazos y el pueblo sigue sin casas y sin luz."11

Más adelante, en su alegato se explican las primeras medidas concretas que se llevarían a cabo en relación con la vivienda después del triunfo de la Revolución:

"Un gobierno revolucionario resolvería el problema de la vivienda rebajando resueltamente el cincuenta por ciento de los alquileres, eximiendo de toda contribución a las casas habitadas por sus propios dueños, triplicando los impuestos sobre las casas alquiladas, demoliendo las infernales cuarterías para levantar en su lugar edificios modernos de

11 Castro (1953), p.37.

26 revista invi № 72 / Agosto 2011 / Volumen N ํㅜ 26: 19-62 two million two hundred thousand people of our urban population pay rents that take from a fifth to a third of their income; and two million of our rural and peri-urban population do not have access to electricity. The same happens if the State reduces the cost of renting, landlords might stop all constructions; if the State does not take any action, they will build as long as they earn high profits, after that, they will not build any more, even the rest of the population is living in the open. Others monopolize electricity by extending the lines until earning satisfactory profits, once this goal is achieved, it does not matter if people live in the dark for the rest of their lives. The State remains quiet and the population still do not have access to housing and electricity ${ }^{11}$.

Later on, the first concrete measures regarding housing, after the triumph of the revolution, were explained.

"A revolutionary government would solve the housing problem by halving the cost of renting, exempting from tax payment all houses inhabited by their owners, trebling taxes on rented houses, pulling down all tenements and putting up modern and large buildings and

11 Castro (1953), p.37. 
muchas plantas y financiando la construcción de viviendas en toda la isla en escala nunca vista bajo el criterio de que si lo ideal en el campo es que cada familia posea su propia parcela, lo ideal en la ciudad es que cada familia viva en su propia casa o apartamento. Hay piedra suficiente y brazos de sobra para hacerle a cada familia cubana una vivienda decorosa. Pero si seguimos esperando por los milagros del becerro de oro, pasaran mil años y el problema estará igual."12

Solo dos años después el movimiento revolucionario anunció una política mediante la cual cada arrendatario se convertiría en propietario. ${ }^{13}$ ¿En qué medida esta categórica recomendación de la pequeña propiedad, que se encontraba en total armonía con la tradición del Héroe Nacional cubano José Martí14, era una desviación consciente de los dogmas marxistas? Esto, que será abordado posteriormente en el artículo, al menos habla a favor de la independencia de la vía cubana de solución. En años posteriores, Fidel Castro se manifestó al respecto como sigue:

"No es una obra por sí marxista. Es la expresión de un pensamiento en desarrollo, de una serie de

2 Castro (1953), p.42.

13 Castro (1955), p. 218

14 José Martí citado en INAV (1960), p.14.

ARTICULO: 50 años de la ley de reforma urbana en Cuba. En el aniversario del cambio de paradigma / Erich Trefftz financing the construction of dwellings across the island at an unprecedented scale. The ideal is that every family living in the countryside has their own plot and every family living in the city has their own house or apartment. There is enough material and manpower to build a decent dwelling to every Cuban family. However, if we are still waiting for the miracles of the golden calf, it will be a thousand years and the problems will remain the same ${ }^{12 "}$.

Two years after the revolutionary movement, Castro announced a policy in which every tenant became owner ${ }^{13}$. To what extent did this categorical recommendation of the small property, in harmony with the tradition of Cuba's national hero Jose Martí14, represent a conscious alteration of Marxist dogmas? Such a question, which is discussed in this paper, supports the independence of the Cuban solution. In later years, Fidel Castro stated:

"It is not a Marxist action. It is the expression of a developing thought, a series of ideas that have been part of the revolution... ${ }^{15}$ "

12 Castro (1953), p. 42

13 Castro (1955), p. 218

14 José Martí quoted in INAV (1960), p. 14

15 Fidel Castro quoted by Fernández Núñez (1976), p.86 when asked on the historical importance of his defense statement. 
ideas que han formado parte del quehacer revolucionario (...)"15

\section{Las primeras leyes revolucionarias, la Ley de Reforma Urbana y el desarrollo de la política de la vivienda}

\begin{abstract}
Según Hamberg “(...) las políticas pos revolucionarias de la vivienda en Cuba se vieron influenciadas por diversos factores, entre los cuales pueden mencionarse las drásticas diferencias de condiciones de vida entre la ciudad y el campo y entre clases sociales dentro del área urbana, el control de alquileres coexistiendo con altas rentas y un derecho de permanencia establecido por ley junto con evicciones generalizadas."16

Como se puede deducir, en la etapa que precedió al triunfo de la Revolución la vivienda se había convertido en uno de los problemas más acuciantes a los que se veía enfrentada la población. Frente a una elevada demanda insatisfecha, había una insuficiente actividad constructiva, inaccesible para amplias capas de la población; la presión de la de-

15 Fidel Castro citado por Fernández Núñez (1976), p.86, respondiendo a una pregunta acerca de la importancia histórica de su alegato de defensa.

16 Hamberg, (1994), p.27.
\end{abstract}

28 revista invi № 72 / Agosto 2011 / Volumen № 26: 19-62
The First Revolutionary Laws, the Urban Reform Law and the Development of the Housing Policy

According to Hamberg “... post-revolution housing policies were influenced by different factors, such as the dramatic differences in terms of quality of life between the city and the countryside and between social classes within the urban area; lease control coexisting with high rents; and the right to remain established by law along general evictions." 16

The previous paragraph indicates that prior to the triumph of the revolution, the housing issue was one of the most urgent problems faced by the population. Together with an unmet demand, there was insufficient construction activity, which was inaccessible for most of the population. In addition, the demand for housing meant the increase in the cost of renting and evictions to tenants ${ }^{17}$.

16 Hamberg, (1994), p. 27.

17 Corneado estimates 70.000 forced evictions prior to the Revolution, Cf. Corneado (1962), p. 14. It should also be taken into account that there were strikes and production stoppages during the revolutionary transformation. 
manda de viviendas representaba para los arrendatarios amenazados por el desempleo el peligro latente del aumento de los alquileres y el desalojo. ${ }^{17}$

Breves semanas después del triunfo de la Revolución fueron promulgadas las primeras leyes con importancia en el campo de la política de la vivienda. Se trataba de leyes sobre el cese de los procesos por desalojo y las demandas de desahucio (Ley No 26 del 26.1.1959), sobre los precios máximos y la venta forzosa de terrenos urbanos edificables para combatir la especulación (Leyes N. 218 del 7.4.1959; No 691 del 23.12.1959 y No. 892 del 14.10.1960), y la muy esperada, y ya en 1953 anunciada, ley sobre las reducciones de los alquileres (Ley No. 153 del 10.3.1959), mediante la cual se redujeron los alquileres de los inmuebles urbanos de un 30 a un $50 \%$.

Después de una larga elaboración y de incontables debates $^{18}$, el 14 de octubre de 1960 fue promulgada la LRU, declarada como parte de la Ley Fundamental, otorgándosele de este modo el rango constitucional $^{19}$, por su relevancia y trascendencia también en el contexto internacional. Con la proclamación

17 En este sentido, Corneado habla de un promedio de 70.000 desalojos forzosos en la época previa a la Revolución, Cf. Corneado (1962), p. 14; a esto se debe sumar que en las semanas en que transcurrieron estas transformaciones revolucionarias se produjeron considerables paros de la producción y del trabajo.

18 Vega Vega (2000), Capítulo 4.

19 Disposición Final de la Ley en "Seis Leyes de la Revolución“ (1973) p. 99 y s.; Canton Blanco (1982), p. 446.
Shortly after the triumph of the revolution, the first important laws regarding housing were enacted. These laws were about the end of evictions and eviction orders (Law $N^{o}$ 26/01.26.1959), maximum costs and the forced sale of urban building sites in order to face speculation (Laws $N^{o}$ 218/04.07.1959; $N^{o}$ 691/12.23.1959 and $N^{o}$ 892/10.14.1960) and the anticipated law regarding the reduction of renting costs (Law No 153/3.101959), which meant the decline in the rent of dwellings from $30 \%$ to $50 \%$.

After a long elaboration and innumerable debates $^{18}$, the Urban Reform Law was enacted on October 14, 1969 and it was declared as part of the Fundamental Law, thus having a constitutional level ${ }^{19}$ because of its relevance and international importance. In enacting this law, the last reform promise announced in the pre-revolutionary program was fulfilled ${ }^{20}$. In this way, significant decisions were made regarding property law and housing policies.

18 Vega Vega (2000), Chapter 4.

19 Final Provision in "Six Laws of the Revolution", p. 99 and s.; Canton Blanco (1982), p. 446.

20 "... additionally, it was the only item remaining from Moncada's program. Therefore, it has its roots in that period..." Castro (1960), p. 23 
de esta ley se cumplió la última de las promesas de reforma anunciadas en el programa pre- revolucionario ${ }^{20}$. De este modo se habían tomado trascendentales decisiones en materia de derecho de la propiedad y de la política de la vivienda:

Se traspasó el fondo completo de viviendas de alquiler en propiedad a sus correspondientes habitantes; los antiguos propietarios fueron indemnizados por el Estado según el año de construcción y monto del alquiler de la vivienda perdida; se decretó la eliminación y prohibición de todos los gravámenes hipotecarios sobre inmuebles urbanos; se eliminó la institución legal del alquiler de viviendas y se prohibió toda forma de alquiler entre particulares.

En 1984 y 1988 se decretaron con poca separación de tiempo dos sucesivas Leyes Generales de la Vivienda (LGV, Ley $N^{o} 48$ del 31.12.1984 y Ley $N^{\circ}$ 65 del 23.12.1988)

La política pos revolucionaria de vivienda se analiza en el presente trabajo sobre la base de tres elementos relacionados:

1. La propiedad y otras formas de tenencia de viviendas: incluye los atributos de las diferentes formas de tenencia, como los derechos, deberes y responsabilidades para la conservación,

20 “(...) Además era el único punto que faltaba del programa del Moncada. Así es que tiene sus orígenes en aquella época..." Castro (1960), p. 23.

30 revista invi № 72 / Agosto 2011 / Volumen N ${ }^{0} 26: 19-62$
Ownership of all rented houses was transferred to tenants; former landlords received compensatory payment based on the year of construction and the rental cost of the expropriated dwellings; elimination and prohibition of all mortgage taxes on urban dwellings was declared; legal institution of house leasing was eliminated and any form of private renting was prohibited.

In 1984 and 1988, two consecutive Housing General Laws were enacted (GLH, Law $N^{\circ}$ 48/12.31.1984 and Law $N^{o}$ 65/ 12.23.1988).

This paper analyzes the post-revolution policy based on three interrelated elements:

1. Property and other forms of housing tenure: It includes the characteristics of the different forms of tenure, such as rights, duties and responsibilities for the conservation, repair and functioning of single-unit and multiple unit buildings, as well as the security of tenure.

2. Construction and distribution of dwellings.

3. Funding of housing. 
reparación y funcionamiento en edificios de viviendas uni o multifamiliares, así como la seguridad de tenencia;

2. La construcción y distribución de viviendas;

3. El financiamiento de la vivienda.

\section{LA PROPIEDAD Y OTRAS FORMAS DE TENENCIA DE VIVIENDAS}

El gobierno revolucionario se decidió desde el inicio por la propiedad como forma predominante para la tenencia de viviendas, lo cual fue reconfirmado por las dos sucesivas Leyes Generales de la Vivienda (LGV) de los años 1984 y 1988. Mientras que la cuota de propiedad está por encima del $83 \%$, las restantes para el 100\% son viviendas inadecuadas, que no cumplen los requisitos mínimos para ser vivienda de propiedad (por ejemplo, tener una superficie útil de $25 \mathrm{~m}^{2}$ y baño propio, entre otros requisitos), o se encuentran en propiedad de organismos o empresas (las llamadas viviendas "vinculadas" o "medio básico"). Sin embargo, recientemente se manifiesta la tendencia a entregar viviendas construidas por el Estado, no en propiedad sino como alquiler.

\section{PROPERTY AND OTHER FORMS OF HOUSING TENURE}

The revolutionary government always thought of ownership as the predominant form of housing tenure. This was reconfirmed by two consecutive Housing General Laws (GLH) enacted in 1984 and 1988. The ownership rate is above 83\% and the rest of dwellings are inadequate spaces that do not meet the minimum requirements to be considered as property (e.g. $25 \mathrm{~m} 2$ of useful floor space and its own bathroom, among other requirements) or belong to entities or companies (the so-called "housing rental assets" or "basic means.") There is now a tendency to deliver State-built housing; however, such dwellings are not handed over to people, they are leased.

Private renting contracts represent a special case. The legal validity of private contracts was abolished after the enactment of the URL. Later on, the first GLH of 1984 carefully authorized these contracts, however, no special conditions regarding legal protection against eviction are specified and the number of legally registered contracts is insignificant ${ }^{21}$.

21 There are about 3,200 permits for rooms and dwellings rentals in Havana, most of them are used for tourism purposes. Only $0.2 \%$ of total dwellings are transferred for long-term rent. See DPV (2006), p. 24.

revista invi № 72 / August 2011 / Volume № 26: 19-62 
Una posición particular ocupan los contratos de arrendamiento de viviendas o habitaciones entre particulares. La validez jurídica de los contratos de arrendamiento entre particulares fue abolida con la LRU. Posteriormente, en la primera LGV de 1984, se autorizó de manera cuidadosa la celebración de estos contratos, sin embargo no se especifican condiciones de protección legal al inquilino contra el desahucio, y es insignificante la cantidad de contratos legalmente registrados ${ }^{21}$.

Con la revolución se produjo un cambio en el concepto del régimen de propiedad, de manera que para evitar la creación de mercados inmobiliarios especulativos, la compraventa de viviendas está prohibida y únicamente se autoriza la permuta de viviendas de valor semejante ${ }^{22}$.

La aplicación de esta ley genera, por un lado, la inflexibilidad ante el cambio de demanda de vivienda y, por otro, mucho más grave, el desarrollo de
The revolution changed property ownership, in this way, buying and selling of housing was prohibited in order to avoid real estate speculation; only housing exchange of equal value was allowed ${ }^{22}$.

The application of this law generates, on the one hand, inflexibility as a result of the change in housing demand; and on the other hand, it involves legal actions ${ }^{23}$ taken to achieve the desired result (such as housing buying and selling).

Apart from rights and responsibilities issues, the competence for the operation, repair and conservation of multiple unit buildings is also included ${ }^{24}$. The GLH contains legal provisions regarding this subject, the National Institute of Housing (NIH) Resolution 4/93 and the
21 En La Habana existen alrededor 3.200 licencias para el alquiler de habitaciones y viviendas; de estas, la mayor parte son para el turismo. Se puede estimar que solamente el 0,2\% del fondo de viviendas son de alquiler privado con el propósito de residencia a largo plazo. Véase DPV (2006), p.24.

22 Teóricamente está prohibido el pago de efectivo para nivelar el valor. En el criterio jurídico es cuestionado si instalaciones o cesiones de, p.ej., cocinas integrales, acondicionadores de aire 0 armarios empedrados de alto valor caen dentro de la prohibición.
22 Theoretically, cash payment to cover the value of a property is prohibited. Legal standards question whether the installation or transfer of fitted kitchens, air conditioning systems, or fitted wardrobes is an illegal act.

23 Fake marriages, transfers free of charge within the legal framework and other ideas.

24 In the case of single or multi-unit dwellings, such responsibility generally lies with the owner. 
acciones ilegales ${ }^{23}$ para lograr el resultado deseado (por ejemplo, la compraventa de una vivienda).

A los legajos de derechos y responsabilidades según la forma de tenencia se les incluye, aparte del derecho de disposición, la competencia para el funcionamiento, el mantenimiento y la reparación de viviendas en edificios multifamiliare ${ }^{24}$. La LGV contiene las regulaciones legales al respecto, que son complementadas por la Resolución 4/93 del Instituto Nacional de la Vivienda (INV) y la Resolución Conjunta del INV, el Instituto de Planificación Física (IPF) y el Comité Estatal de Precios del 25.9.1989.

A contrario de lo que sucede en la mayoría de los países donde la forma de tenencia determina la responsabilidad del morador para el funcionamiento, el mantenimiento y la reparación de su vivienda y/o edificio, en Cuba esto depende de la tipología del edificio. La ley hace distinción entre edificios de administración propia o municipal ${ }^{25}$. A partir de 4 unidades de viviendas los moradores tienen que elegir una junta de administración

23 En particular hay que mencionar casamientos fingidos con intención de divorcio posterior, cesiones gratuitas en el marco de la ley de alquiler y una multitud de otras ideas.

24 En el caso de viviendas uni o bifamiliares se parte generalmente de la responsabilidad del propietario.

25 Edificios bajo administración municipal son aquellos que cuentan con gran cantidad de viviendas, elevado número de plantas, equipos de cierta complejidad (como ascensores, colectores de desechos, intercomunicadores, etc.) (Véase Art.93b de la LGV). En Provincia Ciudad de La Habana se trata de 526 edificios. Véase DPV (2006), p.5.
INV, Physical Planning Institute (PPI), and State Committee of Price Joint Resolution of 9.25.1989 complement this enactment.

Unlike other countries, where tenure determines the responsibility of the inhabitant in relation to the functioning, conservation and repair of the dwelling, tenure situation in Cuba depends on the type of building. The law makes a distinction between private and municipaladministered buildings ${ }^{25}$. For buildings having more than four residential units it is a requirement that dwellers have to form a committee and pay a monthly fee ranging between 3.24USD and 21.60USD, which barely covers electricity expenses ${ }^{26}$. According to legal provisions, the General Directorate of Housing (GDH) bears the functioning costs of large municipal-administered buildings. This complex distribution of operational and repair

25 Municipal-administered buildings are constructions containing a large number of dwellings, floors and complex amenities, such as elevators, garbage chutes, intercom systems, etc. (See Art.93b. GLH). There are 526 buildings of this type in Havana City Province. See DPV (2006), p 5.

26 This symbolic contribution is not enough to maintain basic amenities. A dwelling might lose its value. For tax purposes, this loss of value is known as amortization and it should be compensated by a reserve. 
y están obligados a pagar una cuota mensual para cubrir los gastos, que por lo general oscilan entre 3 y 20 pesos mensuales y alcanza apenas para pagar la electricidad de la escalera ${ }^{26}$. En los edificios grandes bajo administración municipal, según texto legal, la Dirección Municipal de la Vivienda (DMV) asume los gastos corrientes de funcionamiento. En la repartición poco entendible y clara de las responsabilidades para el mantenimiento y reparación está el talón de Aquiles del manejo de la vivienda en Cuba.

El examen de los fundamentos legales, los comentarios a las leyes y algunos trabajos científicos ${ }^{27}$ arrojan otras contradicciones. Primero está la responsabilidad, al menos en el papel, de la DMV respecto del funcionamiento, mantenimiento y reparación de ascensores, bombas de agua y otros equipamientos técnicos en el caso de los edificios de administración municipal. Sin embargo, no parece correcto que el dueño de una vivienda de mayor estándar sea liberado de estos gastos.

Lo mismo sucede con el hecho de que todos los dueños de viviendas en un edificio tengan la misma cuota de copropiedad, como es argumentado

26 Esta más simbólica contribución al funcionamiento no alcanza ni remotamente para mantener las instalaciones básicas. Una vivienda esta sujeta a una constante y hasta progresiva pérdida de valor. Fiscalmente se conoce la pérdida de valor como amortización y tiene que ser compensada por una reserva para el mantenimiento suficiente.

27 Véase Hamberg (1994), p.486, Dávalos (1991), p.227, Vega Vega (1986), p. 146.

34 revista invi № 72 / Agosto 2011 / Volumen No 26: 19-62 responsibilities is the main weakness of Cuban housing management.

The analysis of the legal basis, comments on laws, and scientific studies show contradictions ${ }^{27}$. The first one is related to the role of the GDH in the functioning, conservation and repair of elevators, water pumps and other technical amenities of municipal-administered buildings. However, it does not seem correct that the owner of a higher quality dwelling is exempted from such payments.

Secondly, as stated by Dávalos in his comment on the GLH, all property owners of a building have the same co-ownership shares. That is to say, a small property owner and a large property owner living in the same building have to contribute the same amount of money. There is no regulation on cohabitation in buildings and the scope of horizontal property law is not clear. Dávalos proposes the abolition of such a law; however, this disposition is applied in the

27 See Hamberg (1994), p. 486, Dávalos (1991), p. 227, Vega Vega (1986), p. 146 
ampliamente por Dávalos en su comentario de referencia a la LGV. El dueño de un mini-apartamento tiene que aportar lo mismo que el dueño de una vivienda amplia en el mismo edificio. Todavía no existe una ley que regule adecuadamente la convivencia en edificios y tampoco queda claro hasta qué punto la ley de propiedad horizontal es aplicable. Dávalos plantea la convención de la abolición de esta ley, pero en la práctica inmobiliaria ${ }^{28}$ esta se aplica y el Ministerio de Justicia la ha reeditado en el año 2000. Por último, es de mencionar que la seguridad de la tenencia de una vivienda no solo se refiere a su pérdida por desahucio u otro acto legal o de soberanía, sino también incluye la seguridad técnica o estructural.

\section{LA CONSTRUCCIÓN Y DISTRIBUCIÓN DE VIVIENDAS}

La fundamentación legal para la construcción de viviendas se encuentra en la LGV. En relación con la construcción y distribución es de interés lo siguiente:

a) En qué suelo se construirá;

28 Como inmobiliaria, en Cuba, se entienden edificios de viviendas y oficinas construidos dentro del marco legal de empresas mixtas (joint-ventures) con capital extranjero, prevista para la venta (viviendas) o la renta (oficinas) a extranjeros no residentes permanentes o firmas extranjeras. La modalidad fue suspendida y lo que quedan son alrededor de 200 casos especiales (extranjeros con una vivienda de propiedad en La Habana) y media docena de ruinas de construcción incompletas. real estate activity ${ }^{28}$ and the Ministry of Justice republished it in 2000. Lastly, it is worth mentioning that security of tenure not only refers to eviction or any legal or sovereignty act, but also to technical and structural security.

\section{CONSTRUCTION AND DISTRIBUTION OF DWELLINGS}

The legal basis for housing construction is contained in the GLH. The following concepts are relevant in relation to construction and distribution:

a) The type of land

b) The type of tools

c) The builder, the investor and the end user

A) housing management is greatly influenced not only by housing policies, but also by urban planning and land policies. In market economy countries, where private property over land

28 In Cuba, real estate activity involves the construction of dwellings and offices carried out by joint-ventures with foreign capital. These spaces are available for sale (housing) or lease (offices) to non-permanent residents or foreign firms. This modality was suspended in 2000; today there are 200 special cases (foreigners owning property in Havana) and half a dozen incomplete constructions.

revista invi № 72 / August 2011 / Volume № 26: 19-62 
b) Con qué materiales de construcción;

c) Quién construye, quién invierte y para quién.

A) El manejo de la vivienda se ve influido de forma determinante no solo por la política de la vivienda, sino también por la planificación urbana y la política de suelo. En los Estados de economía de mercado, donde rige la propiedad privada sobre el suelo, su valor puede llegar hasta el 30\% o más del valor total de una construcción en el centro urbano. Después del triunfo de la Revolución se han editado leyes sucesivas para detener la especulación con el suelo urbano edificable ${ }^{29}$.

La Constitución de 1976 pasó el régimen de la propiedad (y con este el del suelo) a un régimen concordante con los principios socialistas, pero nunca se ha cambiado la propiedad personal sobre los solares yermos dentro de urbanizaciones existentes, ni la propiedad de los agricultores pequeños en fincas rusticas (intra) urbanas.

Para un diagnóstico de la situación actual es necesario diferenciar entre la construcción por esfuerzo propio de viviendas unifamiliares y la construcción estatal de edificios multifamiliares. Para la construcción de edificios se eliminó el principal factor de costo al fijar un precio tope (bajo) para el suelo urbanizable, eliminándose así una fuente importante de ingresos para las municipalidades,

29 Para un análisis histórico o sobre los efectos de estas leyes: véase Hamberg (1994), p. 54.

36 revista invi № 72 / Agosto 2011 / Volumen No 26: 19-62 applies, land value can reach about 30\% of the total value of a construction located in the downtown. After the triumph of the revolution, consecutive laws were enacted so as to stopping speculation on urban construction land ${ }^{29}$.

The 1976 Constitution turned the property regime (and thus the land regime) into a system in line with socialist principles; however, ownership over vacant plots within existent housing estate and ownership of small farmers over (intra) urban dwellings have never been modified.

In order to analyze the current scenario, it is important to make a distinction between the construction of single-unit dwellings built by self-builders and the State construction of multi-unit dwellings. In the case of the construction of buildings, the main cost factor was eliminated by fixing a low floor price for land for development, thus eliminating an important source of income for municipalities. These earnings are generated by land planning, such as in market socialist economies. The Municipal Directorate of Physical Planning is in

29 The historical analysis and the consequences of these laws are available at Hamberg (1994), p. 54.

ARTICLE: 50 years of the urban reform law in Cuba. The anniversary of the paradigm shift 
proveniente de la absorción de las ganancias de la planificación de suelo, como se practica en las economías sociales de mercado. La planificación física y la clasificación del suelo urbano son tareas de las Direcciones Municipales de Planificación Física.

Como base para conocer la relación de propiedad de un lote urbano se usa aún el registro de propiedad pre revolucionario, todavía no completamente actualizado $^{30}$.

La selección de particulares que desean construir ${ }^{31}$ una vivienda por esfuerzo propio se rige por los artículos 17-23 de la LGV. Existen tres caminos diferentes para obtener un lote urbanizable o solar yermo ${ }^{32}$ :

- Compraventa o donación de un solar yermo de propiedad personal. Por lo general se trata de lotes pre revolucionarios, que se traspasaron por herencia y nunca han sido construidos.

30 Si una empresa antigua era inscrita como propietaria el Estado es sucesor legal; si una persona natural es inscrita como propietaria el asunto se complica, pues hay que investigar si ella o sus herederos siguen residiendo en Cuba. En caso de que se construya y más tarde aparezca un antiguo propietario con residencia permanente, este será indemnizado con otro terreno de compensación.

31 Hasta febrero de 2010 para recibir una licencia de construcción había que ser seleccionado según méritos sociales y laborales y necesidad habitacional (Resolución 320/2001 y 11/06 del INV, Reglamento para la nueva Construcción y Rehabilitación de Viviendas por Esfuerzo Propio, en: Gaceta oficial (GO) extraordinaria $\mathrm{N}^{0}$.1, v. 24.1.2006). El concepto de selección fue abolido con la resolución 40/2010 (G0 extraordinaria del 17.2.2010).

32 Hay que mencionar que cualquier cesión de terreno o azotea únicamente se autoriza si se presenta una licencia de construcción valida. charge of physical planning and classification of urban land.

As the basis to understand the ownership link of an urban plot, prerevolutionary registration of property is still being used; it is worth noting that such registration is not fully updated ${ }^{30}$.

The selection of self-builders ${ }^{31}$ is governed by Articles 17-23 of the GLH.

There are three different ways to get an urban plot or a vacant plot ${ }^{32}$.

- Sale and purchase or donation of a private vacant plot. Generally, these are unused plots transferred by inheritance

30 If an old firm is registered as the owner of the urban plot, the State is the legal successor; however, if a natural person is registered as owner, the issue becomes complex, as an investigation has to be carried out in order to find whether the owner or his heirs are still living in Cuba. If a building is put up in the plot of an owner with permanent residence, the owner receives another plot as compensation.

31 Until February 2010, social and work merit, as well as housing needs, were required to be granted a building permit (NIH Resolutions 320/2001 and 11/06, Regulations for the New Construction and Rehabilitation of Self-help Housing; Official Gazette (OG), special edition 1, v. 01.24.2006.) This selection method was abolished (Resolution 40/120, special OG, 17.02.2010.)

32 Any transfer of land or roof is authorized as long as a valid building permit is presented. 
- Cesión de un terreno estatal, que no se entrega en propiedad, sino que se cede un derecho perpetuo de superficie, para evitar la especulación;

- Compraventa o donación de una azotea, para construir sobre ella.

El gobierno revolucionario se ha hecho cargo de más de 800 lotificaciones o parcelaciones con diferente grado de urbanización ${ }^{33}$, pero en general no se han producido nuevas parcelaciones o lotificaciones con un mayor número de lotes para la construcción de casas unifamiliares en La Habana.

B) Los seleccionados para construir o reparar una vivienda por esfuerzo propio tienen el derecho de adquirir los materiales en las entidades autorizadas $^{34}$, los que se les venden por precios extremadamente subvencionados ${ }^{35}$. Sin embargo, resulta difícil obtenerlos, pues la gama de ofertas es muy reducida y existen materiales que no se encuentran o al menos no aparecen en el momento en que son requeridos por el avance de la construcción, por lo cual se adquieren

33 Véase Hamberg (1994), p.67.

34 Véase Resolución 10/06 del INV, Reglamento para la nueva Construcción y Rehabilitación de Viviendas por Esfuerzo Propio; i. GO extraordinaria $N^{0} 1, v .24 .1 .2006$.

35 Un saco de cemento de asignación de $42,5 \mathrm{~kg}$ cuesta 4,85 Pesos $\mathrm{MN}$, que equivale a 0,20 .-CUC, mientras en una tienda de divisas el mismo saco se vende a 6,60.-CUC.

38 revista invi № 72 / Agosto 2011 / Volumen No 26: 19-62
- Transfer of perpetual right over State land; in order to avoid speculation, such land is not given as property

- Sale and purchase or donation of a terrace roof for building purposes

The revolutionary government has carried out more than 800 divisions of land with different urbanization levels ${ }^{33}$; however, no new division of land for the construction of single-unit dwellings has taken place in Havana.

B) those selected to build or repair a house on a self-help basis have the right to get the materials they need on authorized entities ${ }^{34}$ at subsidized prices ${ }^{35}$. Nevertheless, it is difficult to obtain these elements because of the reduced supply; as a consequence, such materials are obtained in black markets, grey markets ${ }^{36}$ or hard-currency stores, where tax on items rises 10 to 50 times.

33 Hamberg (1994), p. 67.

34 See NIH Resolution 10/06, Regulations for the New Construction and Rehabilitation of Self-help Housing; i. special OG, 1, v. 24.01.2006.

35 A $42.5 \mathrm{~kg}$ of a subsidized sack of cement costs 0.20 CUC 10.22 USD); in hard-currency stores, this same product costs 6.60 CUC (7.13 USD).

36 Stolen, embezzled or illegally introduced products are sold in black markets; speculative resale of seemingly legal products, or the acquisition and circulation of unlicensed products are activities related to grey markets.

ARTICLE: 50 years of the urban reform law in Cuba. The anniversary of the paradigm shift 
en el mercado negro o gris ${ }^{36}$, o en las ferreterías de recaudación de divisas, donde los precios gravados con impuestos pueden llegar a ser de entre 10 a 50 veces más que los de los materiales asignados.

Los mercados grises y negros toman como referencia la estructura de precios de los mercados en divisa, pero son influenciados además por la relación entre la demanda y la oferta, particularidades regionales y tradiciones.

Existen mercados grises en artículos de plomería, que se alimentan de productos escasos comprados para la reventa a precios especulativos. También existen mercados grises en materiales reciclados, como acero recuperado y un sustituto para la arena obtenido de los escombros de los derrumbes urbanos. Además, hay productores locales, muchas veces cooperativistas, de canto, ladrillo y mosaico, que están autorizados a vender libremente a la población.

En la construcción estatal de edificios multifamiliares, los inversionistas o empresas constructoras dependen de los materiales de construcción asignados según los planes económicos estatales. Ellos compran directamente a los productores nacionales, y según la posición jurídica del inversionista, im-

36 La definición entre mercados negros y grises se efectúa de la manera siguiente: en los mercados negros se trata de mercados con productos robados, malversados o desviados de otra forma; en el mercado gris se trata de la reventa especulativa de productos aparentemente legales o de la obtención y puesta en circulación de materiales de construcción sin licencia.
Black and grey markets operate based on the price structure of hard-currency stores and are influenced by the relation between supply and demand, regional special features and traditions.

There are grey markets specialized in plumbing articles, in these markets, scarce items are purchased for resale at speculative prices. There are also grey markets specialized in recycled materials, such as steel and a substitute for sand obtained from the debris left by urban demolitions. In addition, there are authorized local producers of pebble, bricks and mosaic; most of these producers are member of a cooperative. In the case of State construction of multi-unit buildings, investors and companies depend on building materials assigned according to State economic plans. This group buys directly from local producers and, according to the legal position of the investor, imports or purchases from foreign representatives provided that there are availability of currency. 
portan o compran a representantes extranjeros, siempre y cuando tengan disponibilidad de divisas.

El costo se estima según un catálogo central de precios de la construcción (el Precons), que se actualiza esporádicamente y que contiene costos de fuerza de trabajo y de equipos. Los costos de mano de obra se estiman a partir de los salarios estatales, que son insuficientes ${ }^{37}$ y no reflejan los costos reales. El que no tiene habilidades para construir por sí mismo depende de la contratación de artesanos, que trabajan por cuenta propia y cobran entre 100 y 300 pesos por día laboral, no siempre tienen licencia para ejercer su oficio. Los titulares de licencias deben pagar impuestos y aranceles mensualmente, y por el momento no se entregan nuevas licencias ${ }^{38}$. Estos contratistas artesanos no disponen, aparte de las ferreterías de recaudación de divisa, de acceso a bienes de inversión o materiales de construcción, por lo que se dirigen a los mercados negros y grises. Por otro lado, no existe un organismo cooperativo que pueda defender los intereses de los artesanos y al mismo tiempo garantizar estándares mínimos de calidad.

C) Aquí hay que diferenciar entre los que construyen por esfuerzo propio y los constructores/inver-

37 En el sentido marxista, insuficiente para la reproducción de la fuerza laboral.

38 Desde octubre de 2010 la situación ha cambiado, entregándose licencias para el trabajo propio, para absorber trabajadores disponibles (véase el ultimo capitulo).
The cost is fixed by a central inventory of construction prices (Precons), which is sporadically updated and contains manpower and equipment costs. The price of manpower is fixed on the basis of State wages, which are insufficient ${ }^{37}$ and do not reflect real costs. Those who do not have the ability to build their own dwelling depend on the recruitment of artisans who work on their own and charge 100-300CUC (108-324 USD) per day of work; some of these artisans do not have permits. Authorized artisans have to pay taxes and duties on a monthly basis; so far, no new permits have been granted $^{38}$. These contractors, apart from hard-currency stores, do not have access to investment goods or building materials, therefore they resort to black or grey markets. In addition, there is no cooperative entity aimed at defending the interests of artisans and ensuring minimum quality standards at the same time.

C) Here, another distinction between selfbuilders and State builders/investors is needed. The procedure to obtain a construction permit is

37 In the insufficient Marxist sense for the reproduction of manpower.

38 The situation has changed since October 2010. Today, permits are granted to self-builders in order to absorb available workers. See last chapter. 
sionistas estatales. El procedimiento para obtener una licencia de construcción es complicado y engorroso $^{39}$. El seleccionado para construir por esfuerzo propio, por su comportamiento social y laboral y su necesidad habitacional, es autorizado a hacerlo únicamente para uso particular y el de su familia.

En el sector estatal de la construcción de viviendas se pueden diferenciar un mínimo de 10 diferentes inversionistas y/o constructores, entre ellos el Ministerio del Interior; el Ministerio de las Fuerzas Armadas Revolucionarias, que con sus empresas constructoras producen viviendas para sus propios empleados; el Ministerio del Azúcar y el Ministerio de la Agricultura y la microbrigada ${ }^{40}$. En los últimos años se han desarrollado programas especiales de viviendas para determinados sectores poblacionales, como los trabajadores del Ministerio del Interior y las Fuerzas Armadas, o los médicos internacionalistas que regresan de misiones en el exterior. El desarrollo de estos programas genera urbanizaciones sectoriales y segregación.

\section{EL FINANCIAMIENTO}

También el financiamiento para la construcción de viviendas parte de los principios en materia de

39 Véase nota 30. Aunque no es comprobable que, como describe Schaeffer (2004), los que intentan construir fácilmente deban gastar 1.000 Pesos CUC para conseguir una licencia de construcción, tampoco es algo descartable o improbable. complicated and cumbersome ${ }^{39}$. Those selected, according to social and employment behavior, to build their own dwelling are authorized to do so for family use only.

It is possible to identify ten different builders/ investors within the State-housing construction sector, such as the Ministry of the Interior and the Ministry of the Revolutionary Armed Forces, these entities build housing for their own employees; the Ministry for Sugar Industry, the Ministry of Agriculture and the microbrigades ${ }^{40}$. In the last years, special housing programs have been developed for a specific section of the population, such as the staff of the Ministry of the Interior and the Armed Forces, as well as internationalist doctors who are back home. The development of these programs creates sectoral residential estates and segregation.

\section{FUNDING}

Funding for construction is based on the principles of the housing policy, endorsed after the triumph of the revolution. The new URL

39 See note 30. As Schaeffer (2004) describes, if the fact that those who want to build with ease have to invest 1,000 CUC $(1,080$ USD) to get a building permit it is not proved, it cannot be regarded as improbable given the large quantity of documents involved.

40 See DPV (2006), S.9f 
política de vivienda asumidos después del triunfo de la Revolución. Con la Ley de Reforma Urbana (LRU) fueron eliminados todos los gravámenes hipotecarios existentes sobre inmuebles urbanos y se prohibió el establecimiento de estos en el futuro. Aparte de que la abolida Ley hipotecaria fue reeditada en el año 1999 por el Ministerio de Justicia, para la construcción y rehabilitación por esfuerzo propio no existen en estos momentos líneas de crédito, ni asegurados por hipotecas ni en forma de créditos de consumo. Para viviendas construidas o asignadas de otra manera por el Estado, se conceden préstamos de adquisición con un plazo de vencimiento de entre 10 y 20 años y un interés de $2 \%$ (si el receptor participó en la construcción) o $3 \%$ anuales. A partir de la crisis hipotecaria ${ }^{41}$ en los EE.UU. y algunos países de Europa, es cuestionable si de verdad el sistema hipotecario desarrollado lleva a la formación de capital ${ }^{42}$, pero sí queda claro que la falta absoluta de líneas de crédito no es favorable para construir y conservar viviendas.

Observando el manejo y la política de la vivienda en su conjunto, puede afirmarse que no se trata de un sistema coherente.

41 La crisis hipotecaria (sub-prime crisis) era el inicio de la crisis financiera y económica más grande de los últimos años. La indiscriminada entrega de créditos hipotecarios para la compra de casas a sectores poblacionales sin recursos ni posibilidad de pagar creó una burbuja inmobiliaria sin precedentes.

42 "La importancia de la formación de capital proveniente de títulos de propiedad sobre el suelo y sobre bienes raíces no se puede estimar lo suficiente alto." Lichtenberger, E., (2002), S.62. eliminated all existent mortgage taxes over urban property. While the Mortgage Law was republished by the Ministry of Justice in 1999, there are no credit lines, either as mortgagebacked securities or consumer credit, for self-builders. In the case of State built/given properties, mortgage loans with a term of 1020 years are granted, these include an annual interest of 2\% (if the end user took part in the construction of the dwelling) or 3\%. Looking at the US sub-prime crisis ${ }^{41}$, which included European countries, it is questionable if the current mortgage system generates capital ${ }^{42}$; however, it is clear that the lack of credit lines affect the construction and conservation of housing.

By studying the housing management and the housing policies as a whole, it can be said that it is not a coherent system. Although the decision that promotes ownership as a predominant form of tenure looks promising, owners cannot legally retain their dwellings, or in other cases,

41 The sub-prime crisis was the beginning of the worst financial and economic crisis. The excessive granting of credit mortgages to people without resources created an unprecedented housing bubble.

42 "The importance of the capital generated by titles of property on land and real estate cannot be highly estimated." Lichtenberger, E, (2002), S.62. 


\section{CUADRO 1 \\ MARCO SOCIO-ECONÓMICO}

La Habana es la capital de Cuba, la cuál es, según su constitución, un Estado socialista de Trabajadores, administrativamente dividido en catorce provincias y un municipio especial. Una de estas provincias es la ciudad de La Habana (provincia Ciudad Habana), correspondiente a la zona metropolitana de la Habana y que según el censo de 2002 tiene 2,2 millones de habitantes. Ciudad Habana se compone de quince municipios, cada uno de ellos con su propia estructura administrativa, incluyendo asamblea y consejo municipal. Desde el punto de vista financiero, ni provincias ni municipios cuentan con ingresos propios o impuestos, ya que los dos niveles dependen por completo de transferencias según el plan central, en conformidad con las directrices generales.

Para un entendimiento de las relaciones económicas es importante conocer la circulación paralela de dos monedas nacionales a la vez. Por un lado el Peso Cubano (CUP), también llamado moneda nacional (MN), con el que se reciben los salarios, se reparten los productos racionados de la libreta de abastecimiento y se pueden comprar verduras, frutas y carne de producción nacional en los agro-mercados.

Con 25 de estos CUP se adquiere en las casas de cambio estatal un Peso Convertible (CUC). Esta moneda artificial es enganchada al Dólar de EE.UU. (un CUC equivale a 1,08 usd), y se necesita para la adquisición de todos los productos que se importan directamente, contienen partes importadas o se producen dentro del marco de empresas mixtas.

El salario promedio en 2009 en el sector estatal era de 427 CUP (Pérez, 2010:78) y el sueldo de un profesor universitario entre 600 y 900 CUP. Según estimaciones, casi un millón de los 3,4 millones de núcleos familiares cubanos reciben remesas del exterior, con un promedio de 1200 usd anual (Orosco, 2009).

En los primeros tres meses de 2009, las importaciones superaron las exportaciones por casi el cuádruple, y el déficit del comercio exterior creció en 2008 en comparación con 2007 en 68\% (Espinosa Chepe; 2009).

Cuba se menciona después de Indonesia como el país más endeudado (Club de Paris, 2008) y sobrevive económicamente únicamente gracias a la entrega diaria de casi 100.000 barriles de petróleo a precios preferenciales por su aliado estratégico, Venezuela. En los últimos tiempos han aumentado los síntomas de una grave crisis financiera (Pavel 2010). 


\section{CHART 1 SOCIOECONOMIC FRAMEWORK}

Havana is the capital city of Cuba, a country defined by its constitution as a socialist State of workers. Cuba is administratively divided into 14 provinces plus a special municipality. Havana is one of these provinces (Havana City Province), which is identical to Havana's metropolitan area; according to the 2002 census, this city has a population of 2.2 million. Havana City is divided into 15 municipalities; each of them has its own administrative structure, including an assembly and a municipal council. From a financial perspective, neither provinces nor municipalities generate income on their own; they completely depend on transferences made according to the central plan and in accordance with top down orders.

In order to understand economic relations, it is worth mentioning that there are two currencies circulating at the same time. On the one hand, there is the Cuban peso (CUP), also known as national currency (nc). The CUP is used to pay wages and to buy local goods and food. On the other hand, there is the Cuban convertible peso (CUC), which is an artificial currency that is at a fixed one-to-one parity with the American dollar ( 1 CUC $=1.08$ USD). The official exchange rate is 25 CUP $=1$ CUC. The CUC is used to purchase import goods, products containing imported parts and goods manufactured by joint-ventures.

In 2009, the average wage was 427 CUP (426 USD) (Pérez, 2010:78) and the wage of a university professor ranged between 600 and 900 CUP ( 599 and 899 USD). Figures indicate that almost a million of the 3.4 million of Cuban families received remittances from abroad, averaging 1.200 USD per year (Orosco, 2009).

In the first three months of 2009, imports almost quadrupled exports and the foreign trade deficit of $2008 \mathrm{grew} 68 \%$ compared to 2007 (Espinosa Chepe; 2009).

After Indonesia, Cuba is the most indebted country (Paris Club, 2008) and financially survives thanks to the daily provision of 100,000 oil barrels sold at strategic prices by Venezuela, Cuba's strategic partner. In recent times, signs of a severe financial crisis have increased (Pavel, 2010). 
A pesar de que se ha tomado una decisión prometedora a favor de la propiedad de la vivienda como forma de tenencia predominante, el propietario se ve imposibilitado para mantener su propiedad legalmente, o bien tiene que recurrir a los mercados negros o grises. Las razones que dificultan el mantenimiento de la vivienda son:

1. No existen mercados donde se vendan los materiales necesarios para la construcción y rehabilitación de viviendas. Hay que dirigirse a los mercados grises o negros para conseguir, sin garantía, lo que en el momento esté disponible;

2. No existen brigadas de rehabilitación o construcción licenciadas y libremente contratables, ni organismo cooperativo o cámara de oficio que supervisen los trabajos artesanales, teniendo que recurrir a los mercados negros o grises con todas sus consecuencias negativas;

3. No existen líneas de crédito para la rehabilitación ni la construcción, ni existen subsidios dentro del marco de un programa de rehabilitación urbana, con la excepción del centro histórico gestionado por parte de la Oficina del Historiador de la Ciudad de la Habana $(\mathrm{OHCH})^{43}$.

43 La esporádica entrega de unos sacos de cemento y cubos de pintura al delegado del consejo popular (unidad administrativa a un nivel inferior al municipio) no se cuenta como rehabilitación. La Oficina del Historiador de la Ciudad de la Habana (OHCH) y su esfuerzo para rescatar el Centro Histórico a través de una rehabilitación integral es excluida de esta crítica. they have to resort to black or grey markets. Then, housing conservation is affected by:

1. There are no markets where materials for rehabilitation and construction are sold. The option is to resort to black and grey markets, where only available items without warranty are purchased.

2. There are neither freely-hired rehabilitation or legally constituted construction brigades, nor a cooperative entity or chamber of handicrafts in charge of supervising selfbuilders. As a result, people resort to black and grey markets and its negative consequences.

3. There are neither credit lines for rehabilitation and construction, nor subsidies as part of an urban rehabilitation program; the exception is the historic center, which is managed by the Office of the Historian of the City $(\mathrm{OHC})^{43}$.

43 The sporadic delivery of cement and paint to the representative of the poplar council (administrative unit that is one level down the municipality) is not regarded as rehabilitation. The Office of the Historian of the City $(\mathrm{OHC})$ and the efforts to rescue the Historical Center through a comprehensive rehabilitation is excluded from this critic. 
4. En el caso más complejo de los edificios multifamiliares, todavía no existe una 'ley de propiedad horizontal' adaptada a las circunstancias peculiares cubanas. No existe para la Junta de Administración de estos edificios la posibilidad de desarrollar una personalidad jurídica propia, para mantener una cuenta bancaria y negociar préstamos;

5. La prohibición de vender y comprar viviendas hace legalmente imposible para el propietario adaptarse a circunstancias nuevas, como por ejemplo, reducir el consumo de vivienda por falta de capacidad financiera para mantenerla o cambios en el núcleo familiar.

Estas carencias del sistema de la vivienda, junto a la crisis socio-económica, que afecta por igual a los individuos y al gobierno (véase Cuadro 1), ha contribuido a agravar el estado técnico y de mantenimiento del fondo edificado. El deterioro es aún mayor en gran parte de las zonas centrales de La Habana, que por sus características constructivas (edificios viejos de apartamentos y casas de vecindad) dificultan aún más la iniciativa privada de rehabilitación de viviendas. Los datos oficiales sobre el estado estructural y técnico de la vivienda son contradictorios. Según las cifras mencionadas en el V Encuentro Internacional sobre Manejo y Gestión
4. As regards the complexity of multiunit buildings, there is no "horizontal property law" adapted to Cuba's particular circumstances. The management committees of each of these buildings do not have legal personality so as to keep and account and ask for loans.

5. Ban on the sale and purchase of housing makes legally impossible the adaptation to new circumstances, such as the reduction of housing consumption as a consequence of financial problems or changes within the family.

These housing shortcomings, along with the socioeconomic crisis that affects the people and the government alike, have worsened the technical and conservation state of constructions. See Chart 1. In this context, the deterioration level of housing in the downtown areas of Havana is even worse due to the characteristics of dwellings (old buildings and tenement houses), making it difficult for the private sector to rehabilitate such constructions. Official information regarding the structural and technical state of housing is contradictory. 
de Centros Históricos ${ }^{44}$, el 50\% de las viviendas en el Casco Histórico de La Habana se encuentran en mal o muy mal estado, y en ellas vive un 59\% de la población. Esto es válido también para los demás barrios céntricos.

Otro aspecto discutible de la política cubana de vivienda es la indiscriminada subvención de la poca construcción de viviendas.

Viviendas terminadas dentro del marco de la construcción estatal son entregadas a sus futuros propietarios al llamado precio legal, desvinculado de la realidad ${ }^{45}$. Por esto el adquiriente de una vivienda nueva de construcción estatal se convierte en receptor de un valor con una muy alta subvención, que se otorga independientemente de las necesidades reales del beneficiario, y cuya composición detallada se desconoce o es muy difícil de desglosar.

Para los titulares de licencias de construcción autorizados a construir por esfuerzo propio, la subvención se relaciona con el precio de los materiales y,

44 Veitia Reyes, Z. (2006). Grupo de Información y Colaboración de Consejo de Administración Municipal del municipio de Habana Vieja: Gestión Municipal para la reducción de riesgos, Conferencia dada en el V Encuentro Internacional sobre Gestión y Manejo de Centros Históricos.

45 El precio legal es un sistema para calcular el valor de una vivienda por metros cuadrados. Para la construcción nueva el precio básico oscila entre 65 y 180 CUP por metro cuadrado; a este se añade un recargo en función de las facilidades urbanísticas de lugar (Véase Dávalos (1990), pag.92ss.). Un precio legal por debajo de 10 dólares por metro cuadrado no tiene mucha relación con valores reales.
Figures provided during the $V$ International Meeting on Historic Centers ${ }^{44}$ indicate that $50 \%$ of dwellings located in the Historic District of Havana are in poor or very poor condition; it is worth mentioning that this area concentrates $59 \%$ of the population. This scenario also occurs in the rest of central districts.

The other questionable aspect of the Cuban housing policy is the excessive subsidy on the reduced building activity. Finished State-built dwellings are handed over to the future owners at a legal price, which is not related to reality ${ }^{45}$. For this reason, the acquirer of State-built housing is receiving a highly subsidized asset. Such a property is given regardless of the real needs of the beneficiary, which are unknown or difficult to interpret.

Self-builders holding construction permits are granted subsidy to cover material costs. All

44 Veitia Reyes, Z. (2006) Information and Collaboration Group of the Municipal Administration Council of Old Havana: Municipal Management for Risk Reduction, lecture given in the $\mathrm{V}$ International Meeting on Management of Historical Centers.

45 Legal price is a system used to calculate the value of a dwelling by squared meters. The price of a new construction ranges between 65 and 180 CUC ( 65 and 194 USD) by squared meter. In addition, it has to be added a surcharge depending on the location the new dwelling is going to be built. (Dávalos (1990), p. 92ss.) It is clear that a legal price below 10USD by squared meter has no relation with real prices.

revista invi № 72 / August 2011 / Volume № 26: 19-62 
de nuevo, todos los seleccionados son subvencionados por igual, independientemente de su necesidad real. No permitir la construcción de viviendas sin subvención es una solución demasiado costosa para cualquier Estado. El gráfico 1 ilustra los modos de subvención de la construcción de viviendas hasta finales de 2010. Es de notar que existen solamente dos modalidades principales para la construcción de viviendas: por un lado la construcción estatal de edificios multifamiliares, en la que no solo la construcción del edificio recibe una subvención (fomento del objeto), sino también el usuario final (propietario) es subvencionado a través del precio legal (fomento del sujeto); y por el otro lado, la construcción por esfuerzo propio, donde el particular recibe el subsidio a través del precio de los materiales (fomento del sujeto).

\section{La encuesta y sus resultados}

Entre los meses de marzo y junio de 2010 se aplicó una encuesta a casi cien expertos en el tema de la vivienda en La Habana. A los encuestados se les presentó como problema "el deterioro de las viviendas existentes, el déficit cuantitativo y cualitativo acumulado y el estancamiento en la rehabilitación y construcción. ¿Qué medidas pueden agilizar y revitalizar la construcción y rehabilitación?", y se les pidió, según su apreciación, marcar en una escala de 1 a 5 (determinante $(=5)$, influencia alta $(=4)$, media (=3), débil (=2) y no influye $(=1)$ ) el grado de beneficiaries are equally subsidized, regardless of their real needs. In this way, the prohibition of the construction of unsubsidized housing is a very costly solution for any State. The different modes of subsidization until 2010 are explained in the following graphic (see Graphic 1). It is worth noting that there are only two main modalities for the construction of dwellings; on the one hand, there is the State construction of multi-unit buildings, in which subsidies are granted not only for building construction (promotion of the object), but also for the end user (owner), who is subsidized through the legal price of his dwelling (promotion of people); on the other hand, self-builders are subsidized through the price of materials (promotion of people).

\section{The Survey and Its Findings}

Almost a hundred experts were surveyed between March and June 2010 about "the deterioration of existing dwellings, the accumulated quantitative and qualitative deficit and the stagnation of rehabilitation and construction. Which measures may invigorate and revitalize construction and rehabilitation?" Those polled were asked to rate the influence each of the 27 measures aimed at improving 


\section{GRAFICO 1. SISTEMA DE INSTRUMENTOS DE LA POLÍTICA DE VIVIENDA EN CUBA GRAPHIC 1. SYSTEM OF INSTRUMENTS OF THE CUBAN HOUSING POLICY}

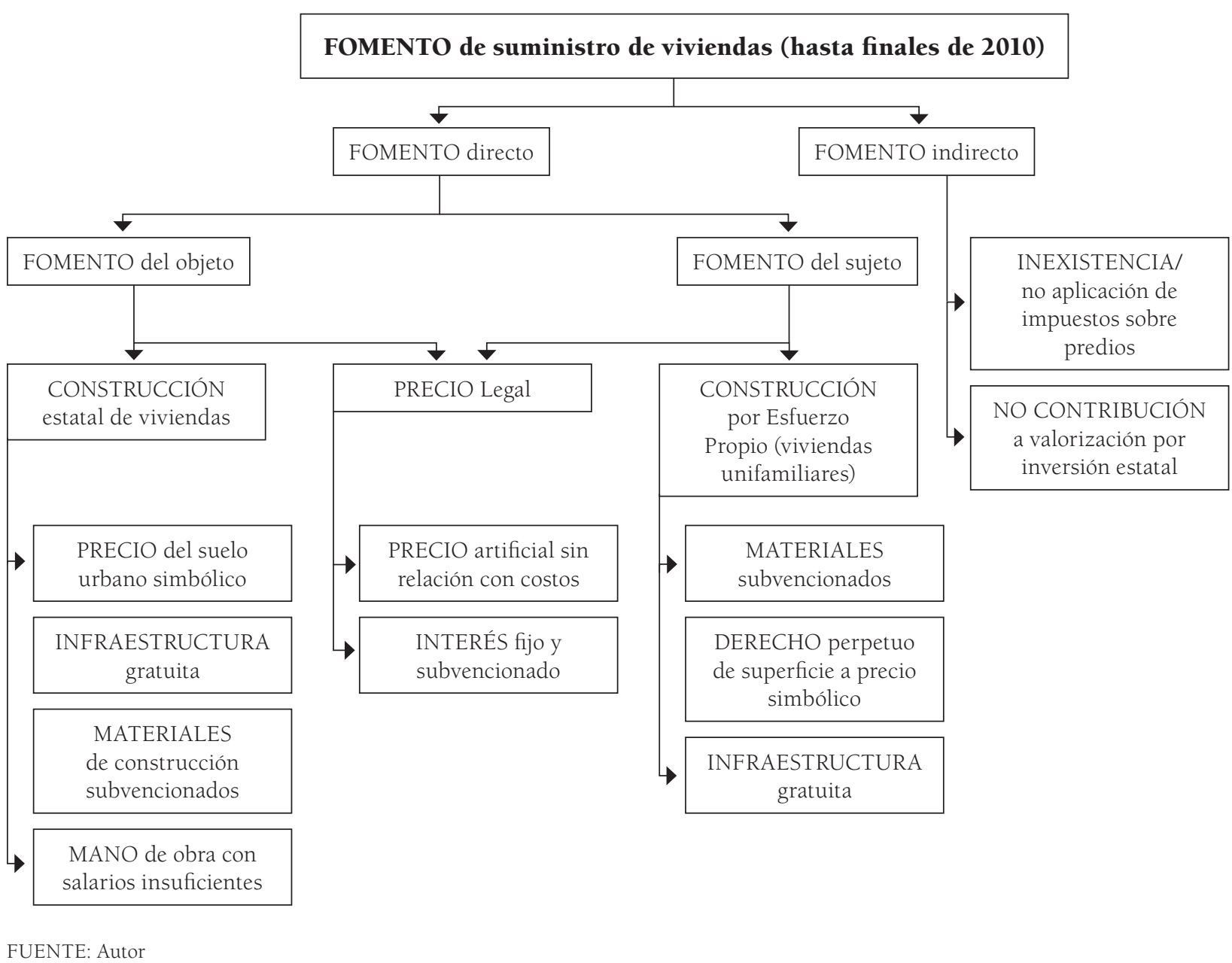


influencia que pudiera tener cada una de las 27 medidas propuestas para el mejoramiento del hábitat.

Las medidas propuestas fueron organizadas en cuatro grupos relacionados con la tenencia, el suelo urbano, la promoción, producción y distribución de la vivienda, así como con el financiamiento, el pago y los subsidios. La mayoría de las encuestas fueron acompañadas por entrevistas personales a los expertos, pidiéndoles opiniones y criterios.

En la Tabla l se presentanlasmedidas propuestascon relación ala tenenciay aspectoslegales de lavivienda.

Probablemente el resultado más notable en este grupo no es el alto grado de influencia que atribuyeron los expertos a la eliminación de restricciones legales en la libre disposición sobre la vivienda o la necesidad de editar leyes adecuadas que regulen la convivencia y las responsabilidades en viviendas multifamiliares, sino el claro rechazo a la especulación con la vivienda y al resurgimiento del desaparecido dueño de apartamentos de alquiler.

La Tabla 2 contiene medidas relacionadas con el suelo urbano. Aquí es sorprendente la relativamente poca importancia que dieron los expertos a la vinculación de la propiedad de la vivienda con la propiedad del suelo. Esto se debe a las dificultades en la imposición de intereses públicos, observadas en otros países de Latinoamérica donde casi la totalidad del suelo urbano es de propiedad privada. habitat may have; to this end, a scale from 1 to 5 was proposed, being 5- decisive; 4- highly influential; 3- influential; 2- slightly influential; and 1- non-influential.

These measures were distributed into four groups, namely, tenure; urban land; promotion, production and distribution of housing; and funding, paymentandsubsidies. Mostsurveyswere complemented with interviews in which experts were asked to provide opinions and guidelines.

Table 1 represents six measures related to tenure and legal aspects of housing. The most remarkable output of this section is not the elimination of legal constraints in the free disposal of housing, or the enactment of laws aimed at regulating coexistence and responsibilities in multi-unit buildings, but the rejection to housing speculation and the rise of the missing landlord.

Table 2 contains measures related to urban land. The slight influence of the linkage between housing ownership and land ownership is striking. This is due to a limited presence of public interests; the same occurs in some Latin American countries, where almost all urban land is privately owned. 
En la Tabla 3 es notable la coincidencia de los expertos en relación con las medidas propuestas. Todas las medidas se evaluaron como de alta influencia y determinantes para el mejoramiento del hábitat. No se manifiesta preocupación por el resurgimiento de la pequeña empresa privada (PYME) para la producción de materiales. En el sector de la pequeña empresa privada se avecinan cambios socio-económicos estructurales, los que se discuten al final del artículo.

En la Tabla 4, en el grupo de medidas relacionadas con el financiamiento, el pago y los subsidios, aparecen nuevamente resultados interesantes. Dadas ciertas particularidades, como larga durabilidad, altos gastos de inversión y pequeña rotación del capital invertido, el sector de la construcción de viviendas requiere de un sistema de financiamiento estable y a largo plazo. La ausencia de crédito para la vivienda dificulta su construcción y rehabilitación. Que la creación de líneas de crédito como medida haya sido una de las más valoradas no es de extrañar. Lo verdaderamente asombroso es el alto grado de rechazo a la hipoteca.

Adicionalmente, hay que mencionar el fracaso en la recuperación de créditos entregados a la población en forma de electrodomésticos a mediados de la primera década del nuevo milenio, y la influencia de la constante propaganda negativa sobre desalojos de viviendas en países capitalistas tras la crisis hipotecaria de 2008 que ha desarrollado la
Table 3 shows how all experts had the same opinion regarding the proposal measures. These initiatives were classified as of highly-influential and decisive for the improvement of habitat. There is no concern for the resurgence of the Small and Medium-size Enterprises (SME) for the manufacture of materials. In addition, there are structural socioeconomic changes ahead for the SMEs; these modifications are discussed at the end of this paper.

Table 4, which is related to funding, payment and subsidies, also shows interesting results. Given certain specific factors such as long durability, high investment expenses and slow capital turnover, the building sector needs a stable and long-term oriented financial system. Lack of housing credit makes the construction and rehabilitation of dwellings difficult. It is no wonder that the creation of credit lines has been chosen as one of the top two measures; however, what was surprising is the high level of rejection to mortgages.

Mention should also be made to both the failed recovery of credit granted to buy electrical appliances and to the influence of negative propaganda about evictions in capitalist countries after the 2008 sub-prime crisis; 
Tabla 1. Medidas relacionadas con la tenencia de la vivienda

Eliminar la prohibición de la compraventa de viviendas entre particulares

Permitir la permuta aun cuando exista desproporción en las valores de la vivienda y permitir la compensación

Promover otras formas de tenencia de la vivienda, como la de alquiler y la cooperativa

3,93

Editar una ley que regule adecuadamente obligaciones y responsabilidades de convivencia,

administración y mantenimiento en edificios multifamiliares, cuarterías y solares

Eliminar la prohibición de tener más de una vivienda en propiedad

\section{Table 1: Measures Related to Housing Tenure}

Lift the ban on the sale and purchase of housing between private persons

Permit the exchange of property, even if there are substantial differences in the price of dwellings

and permit compensation payment

3.93

Enact a law aimed at regulating the obligations and responsibilities of coexistence, administration 3.93

and conservation within multi-unit buildings, tenements and estates

Lift the ban on the possibility of having more than one property 2.15

Enact a law of cooperative housing

Tabla 2. Medidas relacionadas con el suelo urbano

Autorizar la venta de terrenos urbanos y azoteas entre particulares

Vincular la propiedad de las viviendas en edificios de apartamentos con la propiedad del suelo urbano donde ellos se asientan

Reconocer las diferencias en el valor del suelo en función de la localización

Table 2: Measures Related to Urban Land

Authorize the sale of urban land and terrace roofs between private persons

Permit the exchange

Link the ownership of housing in apartment buildings with the property of land

Acknowledge the differences in land value in relation to physical location 


\begin{tabular}{lr} 
Tabla 3. Medidas relacionadas con la promoción y producción de la vivienda y su distribución y & $\begin{array}{r}\text { Valor } \\
\text { consumación }\end{array}$ \\
\hline Entregar licencias de trabajo por cuenta propia en el sector de la construcción & 4,44 \\
\hline Crear mercados abiertos y accesibles de materiales y elementos de construcción y terminación & 4,8 \\
\hline $\begin{array}{l}\text { Crear un organismo cooperativo o cámara de oficios que supervise y garantice la calidad del trabajo y } \\
\text { defienda los derechos de los trabajadores por cuenta propia en la construcción }\end{array}$ & 4,22 \\
\hline Crear un organismo que defienda los derechos de los clientes & 3,94 \\
\hline Autorizar la libre contratación de brigadas/empresas para la construcción, rehabilitación y mantenimiento & 4,47 \\
\hline Promover cooperativas de construcción y venderles medios de trabajo & 4,48 \\
\hline Entregar licencias para construir por esfuerzo propio a todo el que la solicite & 4,33 \\
\hline Ampliar la oferta de vivienda a través de nuevos actores/promotores, como cooperativas y asociaciones & 4,21 \\
\hline sin fines de lucro & 4,22 \\
\hline Posibilitar la creación de pequeñas empresas particulares en el sector de la construcción y rehabilitación & 4,49 \\
\hline Promover la pequeña industria artesanal local en forma de cooperativa & 4,31 \\
\hline Autorizar la pequeña y mediana empresa (PYME) en el sector de los materiales &
\end{tabular}

Table 3: Measures Related to the Promotion, Production, Distribution and Consummation of Housing

Grant self-employment permits for the building sector

Create open markets and ensure the availability of materials and elements for construction and completion

of housing

their work

Create an organization for the defense of the rights of customers

3.94

Authorize the freedom to hire brigades/companies for the construction, rehabilitation and conservation of housing

Promote construction cooperatives and sell work facilities

Grant permits for self-help construction to anyone asking for them 4.48

Expand the housing supply through new actors/promoters, such as cooperatives and non-profit organizations 4.33 Enable the creation of SMEs in the building and rehabilitation sector 4.21 Promote the small local craft industry 4.22 Authorize the SMEs entry into the materials market 4.49 4.31 
Crear líneas de crédito para la rehabilitación y construcción de viviendas 4,72 \begin{tabular}{lr}
\hline Posibilitar la hipoteca sobre propiedades urbanas como fuente de financiamiento & 3,0
\end{tabular}

Posibilitar la constitución de una personalidad jurídica para la administración y rehabilitación de edificios multifamiliares, para manejar cuentas bancarias y buscar créditos

\begin{tabular}{lr}
\hline Concentrar los subsidios en los grupos poblacionales más necesitados & 4,29 \\
\hline Abolir el concepto de precio legal por su no relación con el valor real & 3,75 \\
\hline Promover la formación de cajas de ahorro mutuo o colectivo para la vivienda & 4,02 \\
\hline Declarar zonas céntricas selectas como de emergencia y subsidiar en estas masivamente la rehabilitación & 4,35
\end{tabular}

Table 4: Measures Related to Funding, Payment and Subsidies

Create credit lines for the rehabilitation and construction of housing 4.72

\begin{tabular}{lr} 
Grant mortgages on urban properties as a source of funding & 3.0 \\
\hline
\end{tabular}

Grant legal personality for the purposes of administering and rehabilitating multi-unit buildings, managing bank accounts and asking for loans

Concentrate subsidies on the less favored groups

Abolish the legal price concept due to its non-relation to real price

prensa nacional, lo cual se suma a la historia legislativa en contra del desalojo.

Sólo cuatro expertos insistieron en la importancia de la hipoteca como forma de descongelar el único patrimonio existente en manos de la población, mientras que 20 rechazaron la idea con e argumento de la responsabilidad final del gobierno para el alojamiento de la población. Cómo recon-

54 revista invi № 72 / Agosto 2011 / Volumen N ${ }^{0}$ 26: 19-62 the latter is another episode of the legislative history against evictions.

Only four experts insisted on the importance of mortgages as a way to unfreeze the sole asset of Cuban people. There were 20 experts who rejected this idea by using the argument of the final responsibility of the government for people 
ciliar estos dos extremos será uno de los grandes retos de la política futura de vivienda. En general fue la medida más controvertida de la encuesta y más del 30\% de los expertos confesaron que no conocían el tema o no quisieron responder.

\section{LOS LINEAMIENTOS PARA LA POLÍTICA ECONÓMICA Y SOCIAL Y SUS IMPLICACIONES PARA EL MANEJO DE LA VIVIENDA EN EL FUTURO}

Son muchas las dificultades a enfrentar ante la inexistencia de mercados relacionados con la vivienda (suelo, materiales, mano de obra, capitales y viviendas), la subvención indiscriminada y la simultánea incapacidad para afrontar un financiamiento masivo de viviendas por parte del gobierno.

En el presente artículo no se profundiza en algunas dicotomías, como valor de cambio versus valor de uso, o la vivienda como derecho versus la vivienda como mercancía. Probablemente la exigencia de Jenkis de separar claramente entre la unidad técnica del bien vivienda y el uso de la misma es una manera adecuada de acercarse al problema. El bien técnico constructivo requiere cierta infraestructura e inputs de mercados vinculados, como el de capitales, de suelo urbano, de materiales de construcción, de la fuerza laboral para la construcción y, después, gastos de consumo y de manteni- accommodation. How to reconcile these two opposing extremes? This question is going to be one of the main challenges of future housing policy. In general terms, mortgage was the most controversial measure of the survey and 30\% of those polled either did not know the subject or declined to answer the questions.

The lack of housing markets (land, materials, manpower, capitals and dwellings), excessive subsidies and the incapacity of the government to manage a large-scale funding of housing are major issues.

This paper does not provide additional insight into dichotomies such as exchange value and use value, or the right of housing and housing as a commodity. The requirement proposed by Jenkis to separate the housing asset and its use may be a proper approach to the problem. As for construction, there is the need for infrastructure and capital inputs, land and building materials markets, as well as manpower and expenditures related to consumption and conservation. In addition, there is housing use, which, depending on political resolutions, may be regarded as a social commodity. Once this decision is made, it should be decided which groups of the population 
miento. Por otro lado está el consumo (uso) de la vivienda, que puede, según decisión y normativa política, ser un bien social. Con la decisión política habrá que seleccionar a qué grupos poblacionales se aplica una subvención y el Estado tendrá que tener la capacidad de financiar esta subvención ${ }^{46}$.

El gobierno cubano ha reconocido las dificultades económicas a las que se enfrenta. El 8 de octubre de 2010 fueron editadas en la Gaceta Oficial unas cuantas resoluciones que anunciaban el futuro desempleo de trabajadores estatales sobrantes ${ }^{47}$, amplían el trabajo por cuenta propia ${ }^{48}$, posibilitan el empleo de asalariados por particulares ${ }^{49}$, introducen un sistema unificado para el pago de impuestos sobre ingresos personales ${ }^{50}$ y flexibilizan el arrendamiento de viviendas y habitaciones entre particulares ${ }^{51}$.

Pocas semanas después se divulgaron los "Lineamientos de la política económica y social" 52 para preparar el $6^{\text {to }}$ Congreso del partido celebrado en

46 Véase Jenkis (2001), pág. 249.

47 Resolución $N^{0} 35 / 2010$ del Ministerio Trabajo y Seguridad Social, en G0 Esp. $\mathrm{N}^{0} 12$ del 8.10.2010

48 Resolución $N^{\circ} 32 / 2010$ del Ministerio Trabajo y Seguridad Social, en GO Esp. $\mathrm{N}^{0} 12$ del 8.10.2010

49 Resolución $N^{0}, 32 / 2010$ del Ministerio Trabajo y Seguridad Social, Articulo 5, en GO Esp. N ${ }^{0} 12$ del 8.10.2010 y 33/2010 de Ministerio Trabajo y Seguridad Social, en GO Esp. N ${ }^{0} 12$ del 8.10.2010

50 Resolución N² 281/2010 del Ministerio Finanzas y Precios, en G0 Esp. $\mathrm{N}^{0} 12$ del 8.10 .2010

51 Resolución no.305/2010 de Instituto Nacional de la Vivienda, en GO Esp. No.12 del 8.10.2010

52 Véase PCC, (2010).

56 revista invi № 72 / Agosto 2011 / Volumen N ${ }^{0} 26:$ 19-62 are eligible for subsidization and the State should be capable of funding these subsidies ${ }^{46}$.

Cuban authorities acknowledge that the government is facing financial difficulties. On October 8, 2010, a series of resolutions announcing the unemployment of State supernumerary employees ${ }^{47}$, the extension of self-employment ${ }^{48}$, the possibility for particular individuals to hire people $e^{49}$, the introduction of a unified system for the payment of taxes on personal income ${ }^{50}$ and flexibility for private individuals to rent housing and rooms ${ }^{51}$ were edited in the Official Gazette.

A few weeks later, the "Social and Economic Policy Guidelines" 52 were made available to the public. This framework, designed as a preparation for the VICongress of the Communist

46 Jenkis (2001), p. 249.

47 Ministry of Work and Social Security Resolution 35/2010, OG, special edition $12,10.08 .10$

48 Ministry of Work and Social Security Resolution 32/2010, OG special edition 12, 10.08.10

49 Ministry of Work and Social Security Resolution 32/2010, Article 5, OG, special edition 12, 10.08.10; Ministry of Work and Social Security Resolution 33/2010, 0G, special edition 12, 10.08.10

50 Ministry of Finance and Prices Resolution 281/2010, 0G, special edition $12,10.08 .10$

51 National Institute of Housing Resolution 305/2010, 0G, special edition $12,10.08 .10$

52 See PCC (2010). 
FOTO 1.

CONSTRUCCIÓN

POR ESFUERZO

PROPIO EN EL

BARRIO CÉNTRICO

DEL CERRO.

PICTURE 1. SELF-

HELP HOUSING

IN CERRO'S

DOWNTOWN

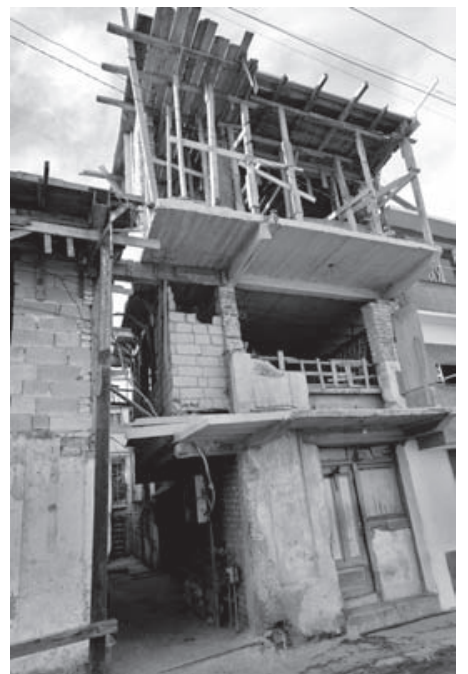

FOTO 2. IMAGEN DE UN EDIFICIO DE VIVIENDAS MUY DETERIORADO, A DOBLAR DEL CAPITOLIO PICTURE 2. HEAVILY DETERIORATED BUILDING NEAR THE CAPITOLIO BUILDING

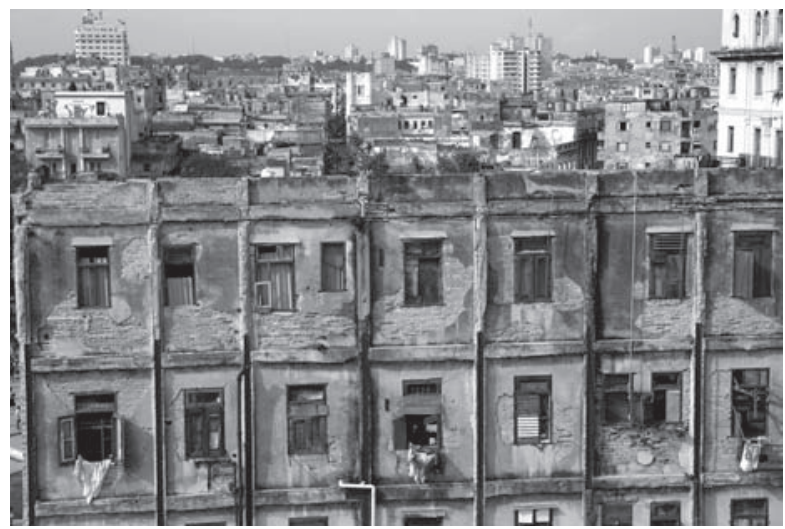

ARTICULO: 50 años de la ley de reforma urbana en Cuba. En el aniversario del cambio de paradigma / Erich Trefftz
FOT0 3. TIENDA CONVERTIDA EN ALBERGUE PICTURE 3. STORE TURNED INTO A SHELTER

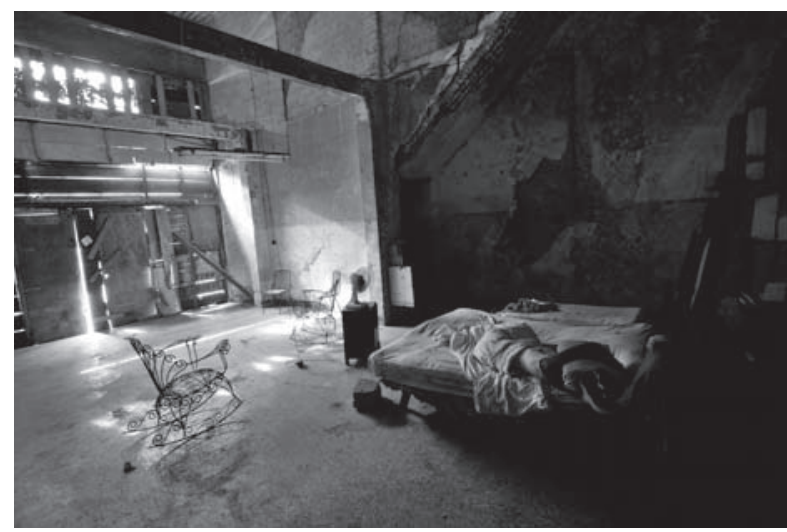

FOTO 4. TIENDA CONVERTIDA EN ALBERGUE EN EL CORAZÓN DE CENTRO HABANA

PICTURE 4. STORE TURNED INTO A SHELTER IN HAVANA'S DOWNTOWN

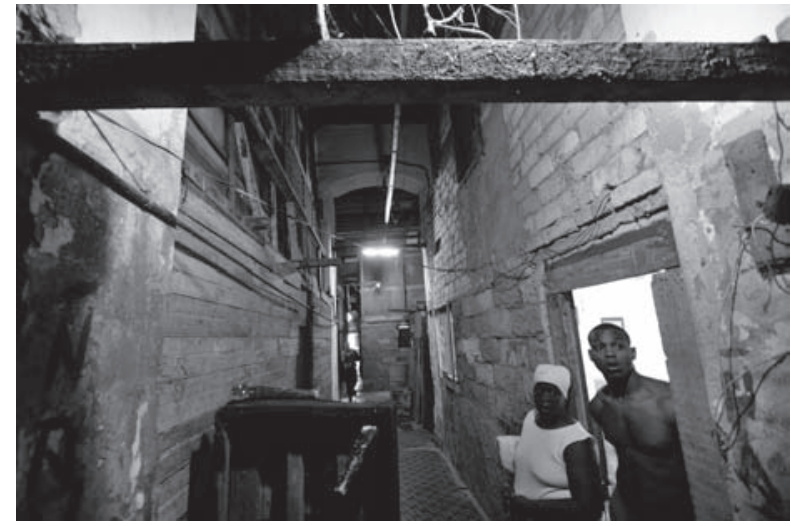

revista invi № 72 / August 2011 / Volume № 26: 19-62

57 
abril de 2011, que flexibilizan para el sector de la vivienda la compra-venta y permuta, promueven nuevas modalidades no estatales para la construcción de viviendas y la venta de materiales de construcción sin subsidios. Además se hace énfasis en "el estudio de los precios de la construcción en un corto plazo para su modificación e implementación, con el objetivo de medir el costo real de las construcciones (...)"53; en la adopción de nuevas formas organizativas en la construcción, como cooperativas y trabajadores por cuenta propia; y en la normalización de los trabajos sin subsidios a ejecutar en edificios multifamiliares.

De lo que se trata ahora es de la aplicación consecuente de estas medidas. Sin embargo, preocupa aún la no inclusión de la política de la vivienda en el listado de políticas sociales a mantener. Por otro lado, tampoco queda claro cómo la población obtendrá el dinero para mantener y mejorar su hábitat, cuando los salarios están tan desvalorizados.

Cinco décadas con muy poca inversión y mantenimiento del fondo existente de la vivienda han conducido a un gran deterioro. No se dispone de estadísticas confiables ${ }^{54}$; sin embargo, la cifra de

53 Cit.: PCC, (2010), Lineamiento $\mathrm{N}^{\circ} 271$.

54 "La falta de estadísticas fiables sobre la vivienda cubana, la parcialidad sectorial de su abordaje, la constante ausencia de indicadores financieros en los análisis, y las variables introducidas por quienes abordan la vivienda más como clave ideológica que como producto técnico-económico, limitan o parcializan el debate fundamentado." Vásquez (2009), p. 50.
Party, brings flexibility to the purchase, sale and exchange of property and promotes new non-State modalities for the construction of dwellings and the sale of unsubsidized building materials. In addition, special attention is given to the "short-term study of building costs so as to modify and implement them with the objective of measuring the real price of dwellings..."53. the adoption of new organizational entities, such as housing cooperatives and self-builders; and the standardization of unsubsidized jobs in multi-unit buildings.

The application of these measures is the next step; however, the absence of a housing policy in the list of social policies is concerning. Additionally, given the devaluation of salaries, the method through which people received subsidies for the conservation and improvement of dwellings is not clear.

Five decades without large investments and conservation of housing have resulted in serious deterioration. There are no reliable

53 PCC, (2010) Guideline 271 
viviendas en mal y muy mal estado en La Habana debe estimarse en más de 200 mil unidades ${ }^{55}$, entre las que se encuentran más de 20 mil viviendas en barrios insalubres, más de 60 mil viviendas en ciudadelas y casi 30mil familias que siguen viviendo con orden de albergarse en viviendas en peligro de derrumbe $e^{56}$.

Si oficialmente se reconoce que "la revolución ha logrado evitar en Cuba la degradación urbana irreversible que se aprecia en las ciudades del resto de Latinoamérica, ha preservado su identidad cultural y ha evitado en sus ciudades la jerarquización espacial y la segregación social" ${ }^{57}$, habrá que preguntarse los costos de estos logros. En los barrios céntricos de La Habana hay derrumbes a diario, y en el afán de buscar soluciones, los mejores locales comerciales de los años '50 se transforman en alojamientos inhabitables, sin iluminación ni ventilación (fotos 3 y 4).

Habría que ver hasta qué punto el arranque económico planificado en los nuevos lineamientos y un desencadenamiento de las fuerzas productivas

55 Estimación del autor, basada en extrapolación de cifras oficiales con cifras exactas obtenidas en zonas reducidas.

56 DPV (2006), pág. 21.

57 Ruiz, Hernández (1998), pág.12. statistics ${ }^{54}$ available; however, the total amount of dwellings in poor or very poor condition in Havana exceeds 200,000 units ${ }^{55}$. Of this figure, there are more than 20,000 dwellings located in districts unfit for habitation, more than 60,000 units located in citadels and about 30,000 families living in dwellings in state of collapse $e^{56}$.

If the fact that "the revolution has preventing Cuba from suffering the irreversible human degradation observed in the rest of Latin American cities, has allowed the preservation of cultural identity and has avoided hierarchybased spatial distribution and social segregation ${ }^{57}$ " is officially acknowledged, then the costs of these achievements should be analyzed. It is common to see the collapse of buildings in Havana's downtown districts, and, in the search for solutions, shopping centers dating from the 50 s are turned into uninhabitable spaces lacking lightning and ventilation. See Pictures 1 and 2.

54 "The lack of reliable statistics on Cuban housing; the biased approach to it; the continuous absence of financial indicators; and the variables introduced by those who address housing from an ideological perspective, rather from a technicaleconomic perspective, restrict the well-founded debate." Vásquez (2009), p. 50

55 Author's estimate based on the extrapolation of government figures in respect of exact figures obtained in reduced zones.

56 DPV (2006), p. 21.

57 Ruiz, Hernández (1998), p. 12 
populares es posible en un escenario donde casi todos los pequeños comercios de esquina fueron convertidos en viviendas y alberges.

El tránsito de las decisiones de principios en el manejo de la vivienda tomadas hace 50 años con la LRU, a partir de una primacía absoluta de lo político sobre lo económico, hacia un manejo de la vivienda sobre la base de principios económicos, es una decisión importante, pero eso no significa aún una decisión sobre cómo diseñar una futura política de la vivienda dentro de una política social que garantiza a los más pobres un hábitat digno.

La selección de los instrumentos para la política de vivienda en Cuba y su dotación financiera dependen esencialmente de si las reformas económicas ${ }^{58}$ iniciadas se reflejarán en un crecimiento económico sustentable para, a través de la recaudación fis$\mathrm{cal}^{59}$, ser redistribuido hacia los más necesitados.

58 Pérez Villanueva (2010), González Mederos (2010), Vidal, Alejandro, (2010).

59 Con la resolución 286/2010, Normas relativas al pago de los impuestos sobre ingresos personales, sobre las ventas, (...) (Gaceta Oficial, $N^{0} 12$ del 8.10.2010), fue por primera vez introducido un sistema tributario unido. Pero los impuestos son altos (ingresos de 100 .- CUC mensuales se agravan con más de $25 \%$, ingresos de 300 .-CUC mensuales con más de 40\%), y es incierto si así se estimula la honestidad fiscal.

60 revista invi № 72 / Agosto 2011 / Volumen No 26: 19-62
Within a context where all stores were turned into dwellings and shelters, the feasibility of the financial injection proposed by the new guidelines and the intervention of popular productive forces remains to be seen.

The transition from the decisions made 50 years ago, where political ideals prevailed over economic interests, to a housing management based on economic principles is an important step; however, this fact does not involve the design of a housing policy aimed at ensuring decent habitat to those deprived of resources.

The selection of instruments for housing policies, as well as its funding, depend on whether the economic reforms ${ }^{58}$ represent a sustainable economic growth; in this way, those in need would receive benefits from tax collection ${ }^{59}$.

58 Pérez Villanueva, (2010); González Mederos (2010); Vidal Alejandro, (2010).

59 The Resolution 286/2010, Norms Concerning Tax Payment on Personal Income, Sales... (OG, 12, 10.08.10) introduced a unified tax system for the first time. However, high taxes (wages of 100 CUC [108 USD] are taxed at $25 \%$ and wages of 300 CUC (324 USD] are taxed at $40 \%$ ) leave uncertainty about the promotion of fiscal honesty. 


\section{Referencias bibliográficas}

ACOSTA, Maruja; HARDOY, Jorge E. Urban reform in revolutionary Cuba. New Haven, Yale University. 1973.

CANTÓN Blanco, Luis. Conferencias de Propiedad y Derechos Reales. La Habana, Editorial del Ministerio de Educación Superior. 1982.

CARNEADO, José F. El problema de la vivienda y la ley de la reforma urbana. Cuba Socialista (2): 10-30, octubre 1962.

CASTRO Ruz, Fidel. Comparecencia por la cadena del FIEL (Frente Independiente de Emisoras Libres). Obra Revolucionaria (27), octubre 1960.

CASTRO Ruz, Fidel. La historia me absolverá, alegato del 16 de octubre de 1953. La Habana, Editorial de Ciencias Sociales. 1983.

CASTRO Ruz, Fidel. Manifiesto No 1 del 26 de Julio al pueblo de Cuba. Pensamiento Crítico (21): 207220, 1968

CLUB de Paris. Amounts due to Paris Club creditor countries. [En línea]. Annual Report 2008. 2008. [Fecha de consulta: 16 diciembre 2009]. Disponible en: http://www.clubdeparis.org/sections/ communication/rapport-annuel-d/annual-report-2008/downloadFile/file/AnnualReport2008. pdf

DÁVALOS Fernández, Rodolfo. La nueva ley general de la vivienda. La Habana, Editorial de Ciencias Sociales. 1990.
DPV. Boletín estadístico Septiembre 2006. La Habana. 2006.

ESPINOSA Chepe, Óscar. Más problemas. [En línea]. Con CUBA. 2009 [Fecha de consulta: 6 febrero 2011]. Disponible en: http://www.concuba.org/ documentos/masproblemas_chepe_encuentro. pdf

FERNÁNDEZ Núñez, José Manuel. La vivienda en Cuba. La Habana, Editorial Arte y Literatura, Instituto Cubano del Libro. 1976. 165 p.

GÓMEZ Gil, Orlando. La propiedad horizontal en Cuba. La Habana, Lex. 1954. 220 p.

GONZÁLEZ Mederos, Lenier. Desarticular el monopolio de la centralización estatal: entrevista a Pavel Vidal Alejandro. [En línea]. Espacio Laical. Febrero 2011 [Fecha de consulta: 23 febrero 2011]. Disponible en: http://espaciolaical.org/contens /esp/ sd_123.pdf

HAMBERG, Jill Mae. The dynamics of Cuban housing policy. New York, University of Columbia. 1994.

HEUER, Jurgen; NORDALM, Volker. Die Wohnungsmärkte im gesamtwirtschaftlichen Gefüge. EN: JENKIS, Helmut (ed.) Kompendium der Wohnungswirtschaft. Munchen, Oldenburg. 2001. p. 23-41. ISBN 3-486-25688-2.

INAV. Revolutionary reform of gambling. Havana, Instituto Nacional de Ahorro y Vivienda. 1960. 32 p.

JENKIS, Helmut. Die Genossenschaften in der Wohnungspolitik. En: LAURINKARI, Juhani (ed.) 
Genossenschaftswesen, Hand- und Lehrbuch München, Oldenbourg. 1990. ISBN 3486217399

LICHTENBERGER, Elisabeth. Stadtverfall und Stadterneuerung. Wien, Verlag der Österreichischen Akademie der Wissenschaften. 1990. 270 p. ISBN 3700117957

MATHEY, Kosta. Self help housing policies and practices in Cuba. En: MATHEY, Kosta (ed.) Beyond self-help housing. London, Mansell. 1991, p. 181216. ISBN 0720120470.

OROSC0, Manuel. The Cuban condition: migration, remittances, and its diaspora. [En línea]. InterAmerican Dialogue. March 2009. [Fecha de consulta 28 febrero 2011]. Disponible en: http://www. thedialogue.org/PublicationFiles/cuban\%20condition\%20migration\%20remittances_FINAL.pdf

PCC. Proyecto de lineamientos de la política económico y social del partido y la revolución. [En línea]. Diario Granma: órgano oficial del Comité Central del Partido Comunista de Cuba. 2010. [Fecha de consulta 23 febrero 2011]. Disponible en: http://www.granma.cubaweb.cu/secciones/Proyecto\%20de\%20Lineamientos\%20del\%20VI\%20 Congreso\%20del\%20PCC.pdf

PEREZ Villanueva, Omar Everleny. Notas recientes sobre la economía en Cuba. [En línea]. Espacio Laical. Marzo 2010. [Fecha de consulta 23 febrero 2011]. Disponible en: http://espaciolaical.org/ contens/23/7581.pdf
RUIZ, Gerardo, HERNÁNDEZ, Eduardo. Política de vivienda en Cuba. Madrid, Documentos. 1998.

SCARPACI, Joseph L.; SEGRE, Roberto; COYULA, Mario. Havana, two faces of the Antillean Metropolis. London, The University of North Carolina Press. 2002. ISBN 9780807853696

VÁSQUEZ, Pedro. De recursos y discursos en la vivienda cubana. Temas. (58):50-57, abril 2009. ISSN 0864-134X

VEGA Vega, Juan. Comentarios a la Ley General de la Vivienda. La Habana, Ed. Ciencias Sociales. 1986. 288 p.

VEGA Vega, Juan. La reforma urbana de Cuba. La Habana. 2000.

VIDAL Alejandro, Pavel. La actual crisis bancaria cubana. [En línea]. Espacio Laical. Marzo 2010. [Fecha de consulta 23 febrero 2011]. Disponible en: http://espaciolaical.org/contens/23/8286.pdf

VIDAL Alejandro, Pavel; PÉREZ Villanueva, Omar Everleny. Entre el ajuste fiscal y los cambios estructurales, se extiende el cuentapropismo. [En línea]. Espacio Laical. Abril 2010. [Fecha de consulta 23 febrero 2011]. Disponible en: http://espaciolaical. org/contens/24/5358.pdf

ARTICLE: 50 years of the urban reform law in Cuba. The anniversary of the paradigm shift 